\title{
Quality of Surface Water and Groundwater in Iraq
}

\author{
Nadhir Al-Ansari', Sabbar Saleh ${ }^{2}$, Twana Abdullah ${ }^{3}$ \\ and Salwan Ali Abed ${ }^{4}$
}

\begin{abstract}
Insufficiency of water resources in the Middle East Region represents vital factors that influence the stability of the region and its progress. Expectations indicate that the condition will be dimmer and more complicated, especially in Iraqi territory. Iraq, which is situated in the Middle East, it covers an area of 433,970 square kilometers and populated by about 32 million inhabitants. Iraq greatly relies in its water resources on the Tigris and Euphrates Rivers as a surface water resources, and several productive groundwater aquifers in which from the hydrogeological point of view divided into several major aquifer units including Foothill, Al-Jazira, Aquifer System, Mandali-Badra-Teeb, Mesopotamian and Desert Aquifer system. Recently, Iraq is suffering from water shortage problems. This is due to external and internal factors affecting the water quality of water resources; they are controlled and uncontrolled factors. The uncontrolled factors are climate change and its consequences, such as reduction of precipitation and temperature increasing. The controlled factors have a significantly negative influence on water resources, but their effects involve more specific regions. The controlled factors are mainly represented by building dams and irrigation projects within the upper parts of the Tigris and Euphrates catchments, Al-Tharthar Scheme, waste water, solid wastes and wastes from wars, which has a significant effect on surface water in Iraq because about $80 \%$ of the water supply to Euphrates and Tigris Rivers come from Turkey.

In addition, the pressures resulting from the high demand for water resources, and the continued decline in their quantity rates have led to major changes in the
\end{abstract}

${ }^{1}$ Lulea University of Technology, Sweden.

2 Tikrit University, Tikrit, Iraq.

${ }^{3}$ Lulea University of Technology, Sweden.

${ }^{4}$ Department of Environment, College of Science, University of Al Qadisiyah.

Article Info: Received: October 27, 2020. Revised: November 1, 2020.

Published online: November 15, 2020. 
hydrological condition in Iraq during the past 30 years. The decrease in surface water levels and precipitation during these three decades reflects the drop in the levels of water reservoirs, lakes, and rivers to the unexpected levels. The level of main country's water source, Tigris, and Euphrates Rivers has fallen to less than a third of its natural levels. As storage capacity depreciates, the government estimates that its water reserves have been reduced precariously. According to the survey from the Ministry of Water Resources, millions of Iraqi people have faced a severe shortage of drinking water.

Since of the importance of water for human life and the need to monitor temporal and spatial changes in quality and quantity, there is a need to develop a general Iraqi Water Quality Index (Iraq WQI) to monitor surface water and groundwater and classify it into five categories, very good, good, acceptable, bad and very bad, in terms of suitability for domestics, irrigation and agriculture depending on the Iraqi and WHO standards for drinking water. In addition, strict establishment for the regular quantitative monitoring surface water and groundwater setting and processes. Prospects are more negative for all riparian countries. This implies that solving these problems requires actual and serious international, regional, and national cooperation to set a prudent plan for water resources management of the two basins. Iraq being the most affected country should seriously set a prudent, scientific, and strategic plan for the management and conservation of its water resources.

Keywords: Pollution, Water Quality, Waste, Surface water, Groundwater, Iraq. 


\section{Introduction}

Deficiency of water resources in the Middle East Region represents crucial factors that control the stability of the region and its progress. Prospects indicate that the situation will be gloomier and more complicated (Frenken, 2009 and Al-Ansari, 2016).

In Iraq, there are external and internal factors affecting the water quality of water within the rives; they are controlled and uncontrolled factors (Al-Ansari, 2013). The uncontrolled factors are climate change and its consequences, such as reduction of precipitation and increasing temperature (Abahussain et al., 2002; Amin et al., 2016). The total water resources within the Arabian Peninsula decreased between 0 and $250 \mathrm{~mm}$ during the period 2002 and 2015 (Frenken, 2009).

The controlled factors have a significantly negative influence on water resources, but their effects involve more specific regions (Al-Ansari et al., 2018 and Adamo et al., 2018). The controlled factors are mainly represented by building dams and irrigation projects within the upper parts of the catchment (Abahussain et al., 2002). Dam building within the upper parts of the Tigris and Euphrates catchments (Turkey, Syria, and Iran) has a significant effect on surface water in Iraq because about $80 \%$ of the water supply to Euphrates and Tigris Rivers come from Turkey (Adamo et al., 2018).

The policy of dam building on Euphrates and Tigris Rivers represents a historical challenge (Solomon, 2010). The Southeastern Anatolian Project (Turkey's Greater Anatolia Project (GAP)) raised this challenge and the tension between Turkey, Syria, and Iraq when Turkey decided unilaterally to construct over 22 dams on both the Tigris and Euphrates Rivers (Bayazit and Avci 1997; Voss et al., 2013). Fourteen of these dams are on the Euphrates River, and the remainder dams are on the Tigris River (Al-Ansari et al., 2018). The planning of GAP is started in the 1970s (Bilgen, 2018). The project includes constructing 19 hydropower plans 52 to produce a total installed hydropower capacity of 7476MWwith annual energy production of 27 billion kilowatt-hours (Ministry of Industry and Technology, 2019). The designed total of irrigated land within Turkey is 1.8 million ha (Bilgen, 2018). The first dam started in operation in 1987. Till this moment (27th of October 2019), 12 dams from this project were completed and are in operation. The last completed dam (27th of October 2019) is Ilisu Dam, which entered the service in 2018. There is another dam (Silvan Dam) that is expected to be completed in a short period (Daggupati et al., 2017). One of the most important consequences of the dams on the Euphrates and Tigris Rivers is decreasing, significantly, the flow of the two rivers and deterioration of the water quality within Iraq (Al-Ansari et al., 2018).

Understanding variations in water quantity and water quality in central and south Iraq in the last two decades and on providing insight for the future had been studied by IOM (IOM, 2020). The report also suggests key recommendations to mitigate the water crisis. 


\section{Surface Water in Iraq}

\subsection{Introduction}

The water resources in Iraq are concentrated to the Tigris and the Euphrates Rivers, which represent together $98 \%$ of the water resources in the country (FAO, 1994). The Tigris and Euphrates rivers are the main sources of water in Iraq with a river basin area of 126,900 $\mathrm{km}^{2}$ for Tigris and $177,600 \mathrm{~km}^{2}$ for Euphrates without tributaries (Frenken, 2009). Both these rivers originate in the highlands of Turkey and share their physical, climatic, hydrologic, and geomorphologic characteristics. However, there are different perspectives on to how treat these two river basins, and some specialists have identified these rivers as twins. Thus, for purposes of integrated water resources management, it is useful to treat them as belonging to a single basin (Kliot, 1994). It is worth to note that the Tigris and Euphrates have different flow patterns and flow rates (Figure 1). These two rivers play an extremely important role for the water availability of this area. Within this area, just these two rivers together with the Nile are classified as large by world standards (Al-Hadithi, 1978). Euphrates and Tigris (with some of their tributaries) originate in the highlands of Turkey, and flow through a region between 45 degrees North and 25 degrees North latitude. Euphrates crosses Syria before flowing into Iraq and meeting Tigris, which also crosses Syria, and together they form Shat Al Arab in the south of Iraq, jointly flowing $190 \mathrm{~km}$ before pouring their water into the Gulf. Iraq is located between latitudes $29^{\circ}$ and $38^{\circ} \mathrm{N}$, and longitudes $39^{\circ}$ and $49^{\circ} \mathrm{E}$ (a small area lies west of $39^{\circ}$ ), encompassing $438,320 \mathrm{~km}^{2}$. It includes $924 \mathrm{~km}^{2}$ of inland waters and it is the 58th largest country in the world (Wikipedia, 2011).

As far as the Tigris and Euphrates Rivers water are concerned, three countries heavily rely on the water of these rivers. These are Turkey, Syria, and Iraq. Turkey depends $98 \%$ on water resources inside its borders, while Syria and Iraq rely only on $28 \%$ and $39 \%$, respectively on water resources inside their borders (FAO, 2017). Despite these facts, water status is affected also by efficiency of water management and water scarcity. For the three riparian countries the published water scarcity indicator (Jammali and Sullivan, 2012; Gassert et al., 2013) suggests that Syria relatively faces the worst situation regarding the availability and use of water resources and the capacity to adapt to water stress. In addition, water resources available per capita are decreasing with time (Figure 1; Shamout and Lahn, 2015). In 2015, 6\% of the people in Syria drink delivered water, and $96 \%$ drink water from improved sources. In Iraq, ESCWA (2003) indicates that the $\mathrm{m}^{3} /$ capita/year was 2100 in 2015, but in 2025 it will be 1750. In Syria it was 1250 in 2015 and it will be 800 in 2025. Both the Tigris and Euphrates Rivers rise within the southeastern parts of Turkey.

The confluence of the Tigris and Euphrates Rivers near the town Qurna forms the beginning of Shatt Al-Arab and it flow southeast wards to reach the gulf (Figure 2). This river is about $195 \mathrm{~km}$ long and its width is about $250 \mathrm{~m}$ and when it passes Basra city $(63 \mathrm{~km}$ south Qurna) the with increases to $700 \mathrm{~m}$ and the elevation of the river drops $0.7 \mathrm{~m}$ [28]. Two tributaries (Karkheh and Karun) rising from Iran join the river 
(Figure 2). Additional source of water to the river comes from minor small tributaries like Garmat Ali, Ezz, and Sweeb which connect the river with the surrounding marshes (Figure 2). The depth of water varies between 6 and $13 \mathrm{~m}$ during dry periods (Abdullah, 2016). The river forms the border between Iraq and Iran for about $95 \mathrm{~km}$.

Shatt Al-Arab River forms the main source of water for domestic, industrial and agricultural activities within Basra Governorate. Wastewater is directly discharged to the river (Abdullah, 2016). In addition, all the water of the tributaries coming from Iran is diverted inside Iran (ESCWA, 2013). This will increase the need for water to fulfill the growing demand and consequently will increase friction and tension within the countries concerned (Al-Ansari, 2016, Akada et al, 2007 and Jones et al, 2008).

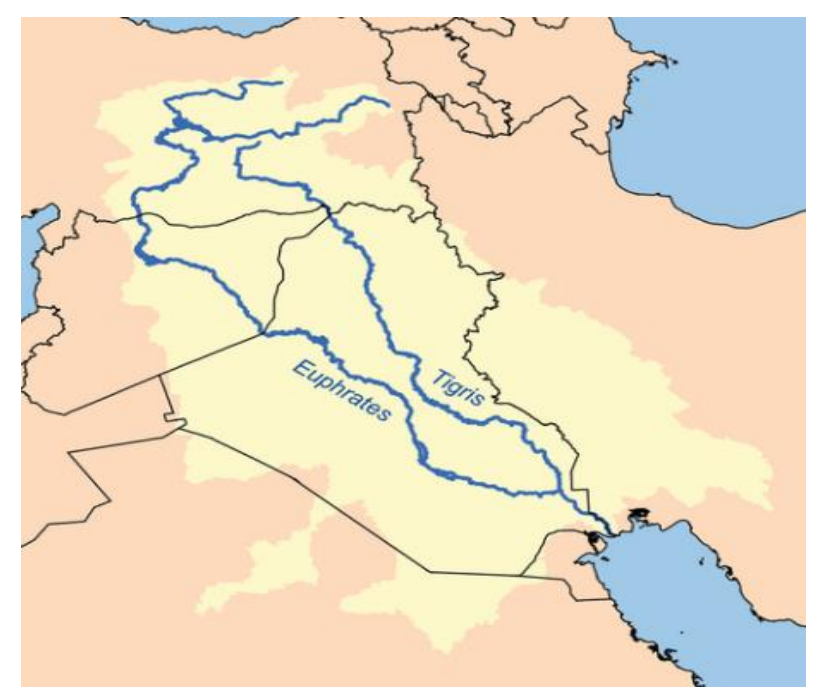

Figure 1: Tigris and Euphrates Rivers. 


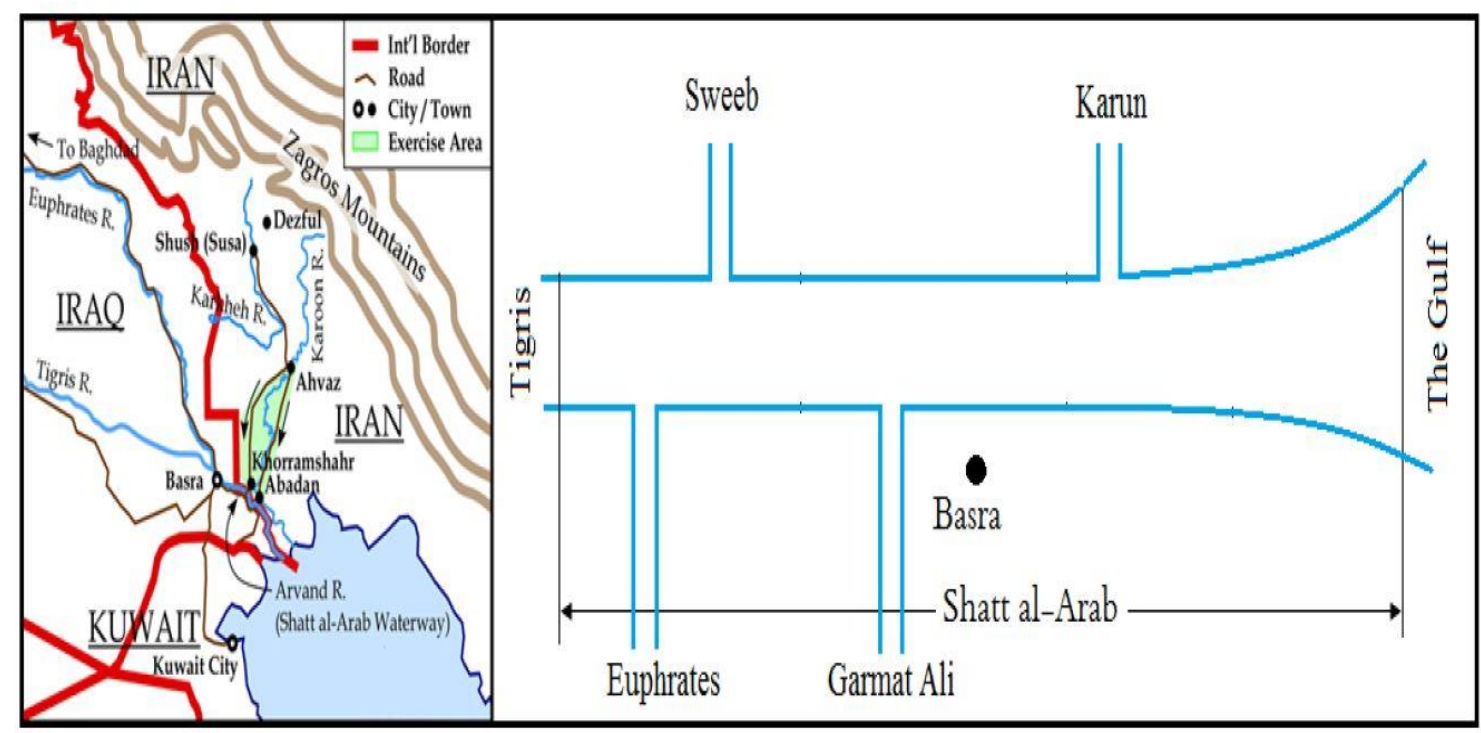

Figure 2: Map and Schematic layout of Shatt Al- Arab River.

\subsection{Surface Water Quality in Iraq}

The water quality index (WQI) value along the Tigris River and the interpolation map for each parameter shows a comprehensive vision about the water quality of the river studied by (Chabuk et al, 2020). The interpolation maps of the WQI distribution along the Tigris River in the wet and dry seasons based on the WQI value at each station of the river calculated in the current study can be seen in Figure 3. According to theses map, water quality along the Tigris River can be classified as good to very poor water quality from different station of collected sample for both the wet and the dry season (Table 1). 
Table 1: Water quality index (WQI) along Tigris River, wet season (2016).

(Tyagi et al. 2013 and Alsaqqar et al. 2015).

\begin{tabular}{|l|c|l|}
\hline \multicolumn{1}{|c|}{ Stations } & WQI & WQR \\
\hline Fishkhabour (1) & 67.077 & Good \\
Mosul Dam (2) & 67.469 & Good \\
Mosul (3) & 71.665 & Good \\
Sharqat (Prediction) & 74.854 & Good \\
Tikrit (4) & 76.948 & Good \\
Samarra (5) & 81.459 & Good \\
Tarmiyah (Prediction) & 86.878 & Good \\
Muthanna Bridge (6) & 91.595 & Good \\
Shuhada Bridge (7) & 95.000 & Good \\
Aziziyah (8) & 101.641 & Poor \\
Kut (9) & 107.339 & Poor \\
Ali Garbi (Prediction) & 116.266 & Poor \\
Amarah (10) & 125.937 & Poor \\
Qurnah (11) & 140.100 & Poor \\
\hline
\end{tabular}

As studied by Al-Ansari et al in 2018, the flow rates of Tigris and Euphrates Rivers are decreasing with time. This has been associated with steady increase of water and soil salinities. The reduction of flow is mainly due to the construction of dams in the upper reaches of the river's basins and huge utilization of water for irrigation purposes. This is coupled with climate change that is affecting the region and causing decrease of annual precipitation with increase in temperatures.

\subsection{Hazard on Surface Water Quality in Iraq}

Due to seasonal fluctuations in Rivers flow in Iraq and the effects of external water control structures along the Euphrates river in upstream countries (Turkey and Syria), and because of Iraq is located downstream of the river, taking in account that most of the head water of Iraqi rivers originate outside of Iraq, water storage was and still is one of Iraq's main priorities. In addition, one should take in account that irrigation periods do not coincide with the maximum flow in the rivers and that Iraq is the most arid of the three riparian countries. Thus, Iraq's water resources are highly correlated with the condition of water resources in upstream countries (Turkey and Syria), which creates an exposed position. All water projects within the river basin undertaken in Turkey and Syria have direct impact on the water flowing into Iraq. This makes Iraq very vulnerable to any changes these two countries make on the rivers. 

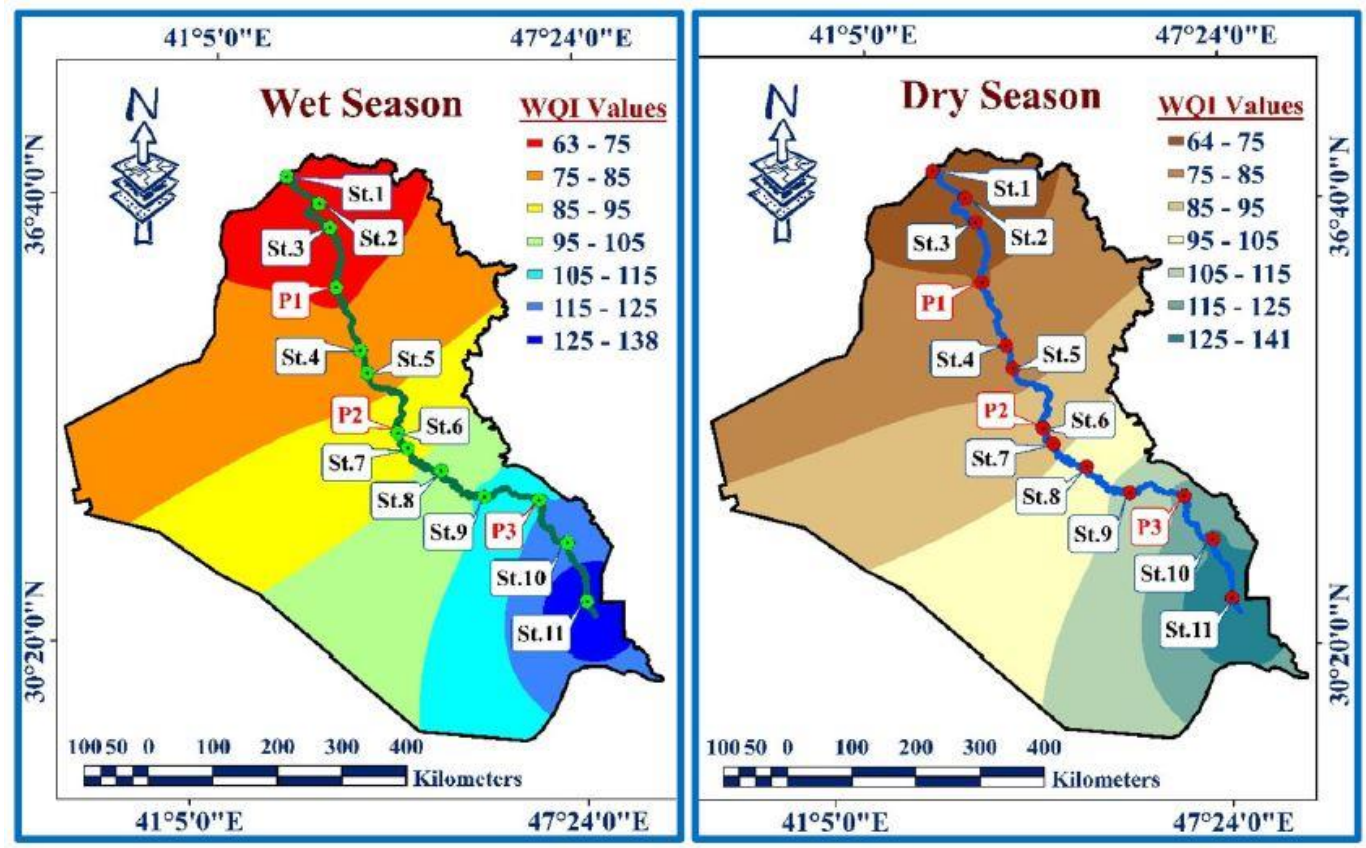

Figure 3: Distribution maps of the Water Quality Index WQI values along Tigris. River in 2016 during a wet season and a dry season. (Chabuk et al, 2020).

The problems in Iraq are more pressing than in Turkey and Syria. Iraq is very dry and flatter making it prone to evaporation. Iraq has extremely dry periods, sometimes lasting up to six months from May to October. The temperature during this time can get up to 120 degrees Fahrenheit. The climate is a major factor in producing high evaporation, but the artificial lakes upstream the dams, which have large open water areas that increase the quantity of evaporation and increase the pollutant concentration in the storage water, also contributes to the loss of water from the system through evaporation.

Urbanization, industrialization, increase in population, and expansion in farming and traditional irrigation systems used, all these factors lead to increased water demand in these three countries. With the construction of many dams in Turkey and Syria, the quantities of water that enter Iraq have decreased, and with the execution of an ambitious water management plan for Turkey (GAP), the quantities of water will decrease more and more.

All the factors mentioned above, in combination with natural factors like climate change and other human activities, which include the intensive use of pesticides and chemicals in farming that follow with the return irrigation flow into rivers, as well as discharging untreated sewage water into waterways, have led to deterioration in water quality and quantity that enters Iraq through the Tigris and Euphrates rivers. Long term records as well as recent data indicate that the salinity of the Euphrates water is considered not acceptable for drinking purposes before it enters the Iraqi border while the Tigris water becomes unacceptable downstream Baghdad (Al- 
Ansari et al , 2018). Water quality deterioration in both rivers is due to several factors. As previously mentioned, construction of dams increased evaporation from the reservoirs. In addition, as more water is used for irrigation purposes the returned irrigation water is expected to seep back to the irrigation network at the absence of drainage systems. Moreover, even at the presence of such systems, drainage water is sometimes discharged directly to the rivers causing increase in salinity. The process is becoming more intensive with the increase of temperatures and decrease of precipitation due to climate change. Other sources for water quality deterioration and pollution includes, (Al-Ansari et al, 2018):

$\checkmark$ Discharge of wastewater to the rivers.

$\checkmark$ Discharging solid waste to the rivers.

$\checkmark$ The use of Al-Tharthar reservoir water to back up Euphrates and Tigris rivers basins shortages

$\checkmark$ Pollutions due to remnants of wars.

$\checkmark$ Increase in water consumption due to high population growth rates.

\section{Groundwater}

\subsection{Introduction}

The pressures resulting from the high demand for water resources, and the continued decline in their quantity rates have led to major changes in the hydrological condition in Iraq during the past 30 years. The decrease in surface water levels and precipitation during these three decades reflects the drop in the levels of water reservoirs, lakes, and rivers to the unexpected levels. The level of main country's water source, Tigris, and Euphrates Rivers has fallen to less than a third of its natural levels. As storage capacity depreciates, the government estimates that its water reserves have been reduced precariously. According to the survey from the Ministry of Water Resources, millions of Iraqi people have faced a severe shortage of drinking water.

These shortages in the water resources have had negative impacts on the agricultural sector in Iraq to the extent that Iraq has subsequently moved from a major wheat exporter to its largest importers in the world. The traditional and unbalanced irrigation and drainage systems have led to a great waste of water resources, pointing to the fact that more than 90 percent of all Iraqi water is consumed in the agricultural sector, which provides only a small percentage of the country's food requirements.

Despite of the Iraqi experience and precious expertise in the field of hydrology, decisions linked to water resources management in Iraq are made based on data achieved from previous scientific mechanisms and techniques. The Accredited and adopted research and studies on this subject are not up to date, and the currently used scientific framework contains many time and spatial gaps, which prevent the approaching of the optimal results required for planning, monitoring and exploitation. Given the terrible coordination and interconnection between the various concerned organizations and directorates, it is difficult to carry out a 
comprehensive and integrated evaluation process. Consequently, there is a lack of understanding of Iraqi groundwater resources and required to the reassessment of water demand through applying the most useful and modern technologies.

There are some facts about the water system in Iraq that can be reviewed prior to entering into the groundwater resources details, including the annual average of precipitation ranges between more than 100 to $1000 \mathrm{~mm}$, and the majority of the annual precipitation occurs from October to April, the average annual water surfaces evaporation is $1300 \mathrm{~mm}$ in the north, $2000 \mathrm{~mm}$ in the center and $2400 \mathrm{~mm}$ in southern Iraq (it may reach $300 \mathrm{~mm}$ per month during July and August).

The national water resources reach $40 \%$ of the total amount, including $8 \%$ of groundwater sources. The annual precipitation fluctuates from year to year with the possibility of drought crisis, in addition to quantitative fluctuations in surface runoff. Lack of prior knowledge of the mode of operation in the water resource from recharging countries of rivers which is equivalent of $60 \%$ of Iraq's water resources, Iraq must depend on its water resources storage collected during a period of several months of the year.

Groundwater quality normally varies laterally and vertically affected mainly by aquifers' boundary conditions moving from an aquifer system to another or even from a geological formation to another in one system. Moreover, water salinity usually develops progressively within a flow media even if it is a single bed due to its salts content dissolution because of groundwater migration between recharge and discharge zones. The geological setting of Iraq allows such a quality profile with its sedimentary cover of 4-13 km thick that overlies the pre-Cambrian basement (Jassim \& Goff, 2006, Figure 4). A sequence of alternating pervious and impervious sedimentary rock beds of course clastics and fractured carbonates with fine clastics and hard rock carbonate, has developed a successive multi aquifer system particularly noted at the Stable Shelf in the western part of Iraq. The space covered by each system or subsystem is that occupied by the spatial surface and subsurface extensions of the composing beds or formations. For simplicity, a formation is considered an aquifer if it can be shown that one or more of its beds is a waterbearing horizon. The hydro geological studies performed in Iraq between Parsons (The Ralf Parsons, 1955) and ASHRI II (SGI, RTI, T-ZERO, and USGS, 2016) have revealed the presence of at least 16 such explored formations in Iraq (Al Jjawad \& Ridha, 2008). Hence, the mapping of these formations may help identifying the lateral boundaries and the vertical overlap between these aquifer systems. It will as well allow to draw a limit between the different water quality groups (salinity range and water type) associated with each aquifer or aquifer system.

Therefore, as groundwater is vital and the sole resource in most of the Iraqi region. It has a significant role in agriculture, water supply and health, and the elimination of poverty in rural areas. Although Iraq is currently dramatically disturbed by complex political and socio-economic problems, fast urbanization and economic expansion are visible everywhere. In addition, salt intrusion from sea waters. Consequently, manage groundwater levels and prevent damage by saltwater 
intrusion, drought, or flooding. The groundwater quality monitoring network provides the data on which measures can be designed and provides the information when to change the settings of your water management system.

\subsection{Distribution of Groundwater Aquifers in Iraq}

The aquifer systems in Iraq are sedimentary rocks to a depth of one kilometer ranging in age between Quaternary and Paleozoic, though Tertiary aquifers are dominant throughout the country. The explored areal extension of each aquifer is introduced by (Al Jawad and Ridha, 2008) who also described their hydraulic conditions and delineate the outcrop extensional areas of their geological formations.

Iraq was divided from the hydrogeological point of view into seven zones by (AlJiburi and Al-Basrawi, 2015), in terms of physiological, structural, geological, and hydrogeological characteristics, each zone has specific hydrogeological and hydrochemical characteristics. These zones can be briefly described as follow (Figure 5):

1. The Mesopotamian Foredeep (Mesopotamian).

2. Low Folded Zone.

3. High Folds Zone.

4. Suture and Thrust Zone.

5. Al-Jazira Zone.

6. Western Desert Zone.

7. Southern Desert Zone.

Whilst groundwater aquifers system in Iraq divided into several major hydrogeological units by (Krasny et al., 2006), as follows, (Figure 6):

1. Foothill Aquifer System.

2. Al-Jazira Aquifer System.

3. Mandali-Badra-Teeb Aquifer System.

4. Mesopotamian Aquifer System.

5. Desert Aquifer system, which includes two aquifers subsystem, the northern and southern. 


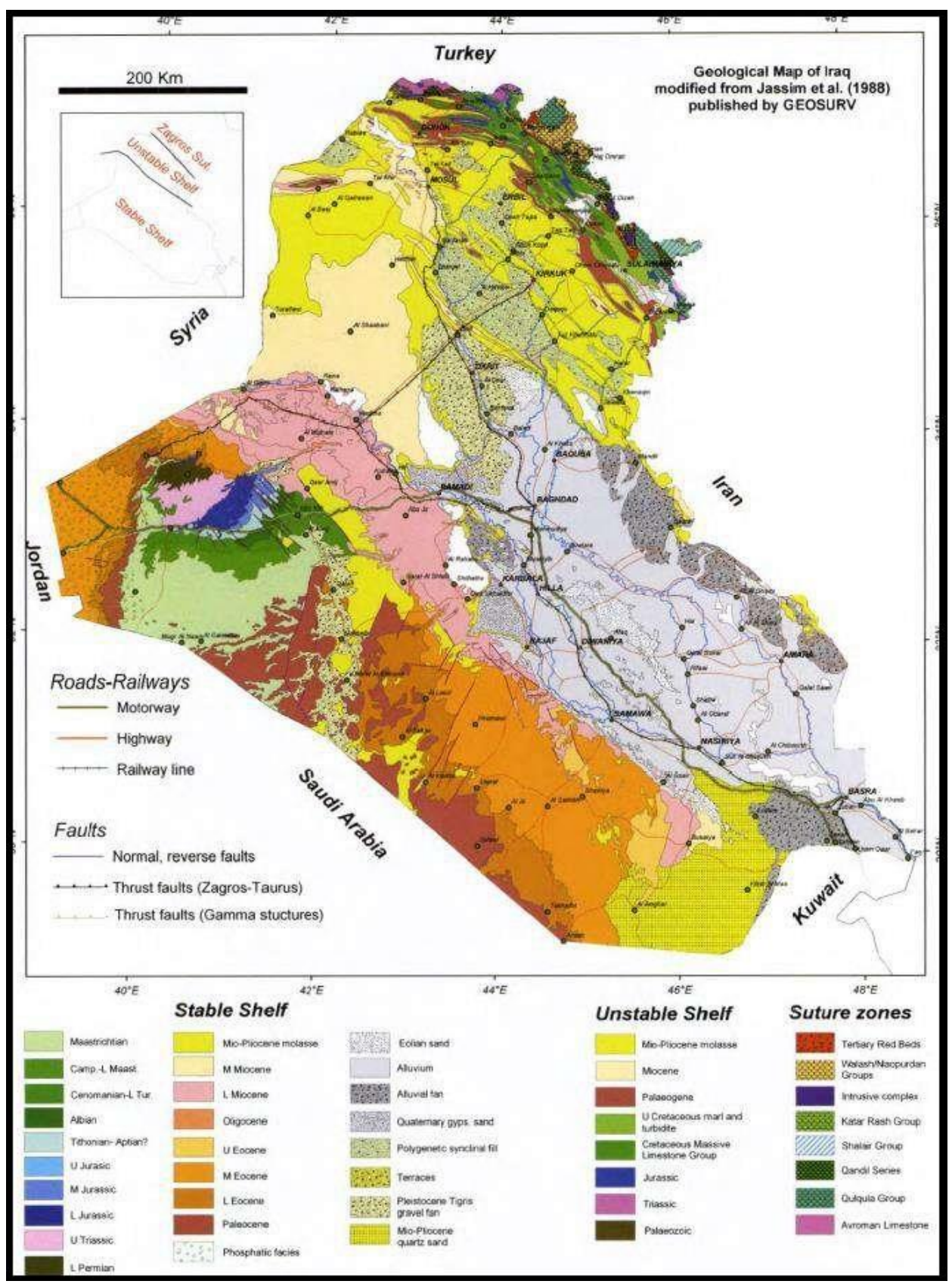

Figure 4: Geological map of Iraq (Jassim \& Goff 2006).

Geological, structural, and lithological conditions govern spatial distribution and extensions of hydrogeological components in terms of aquifers and aquitards, and their hydrological characteristics. Depending on the above-mentioned parameters and on the relationship with the geological formations that storing the groundwater, fourteen major aquifers (or group of aquifers) have been recognized and classified 
by (Krasny et al., 2006) in Iraq. The surface or near-surface spatial extent of these aquifers is illustrated in Figure 5 as follows:

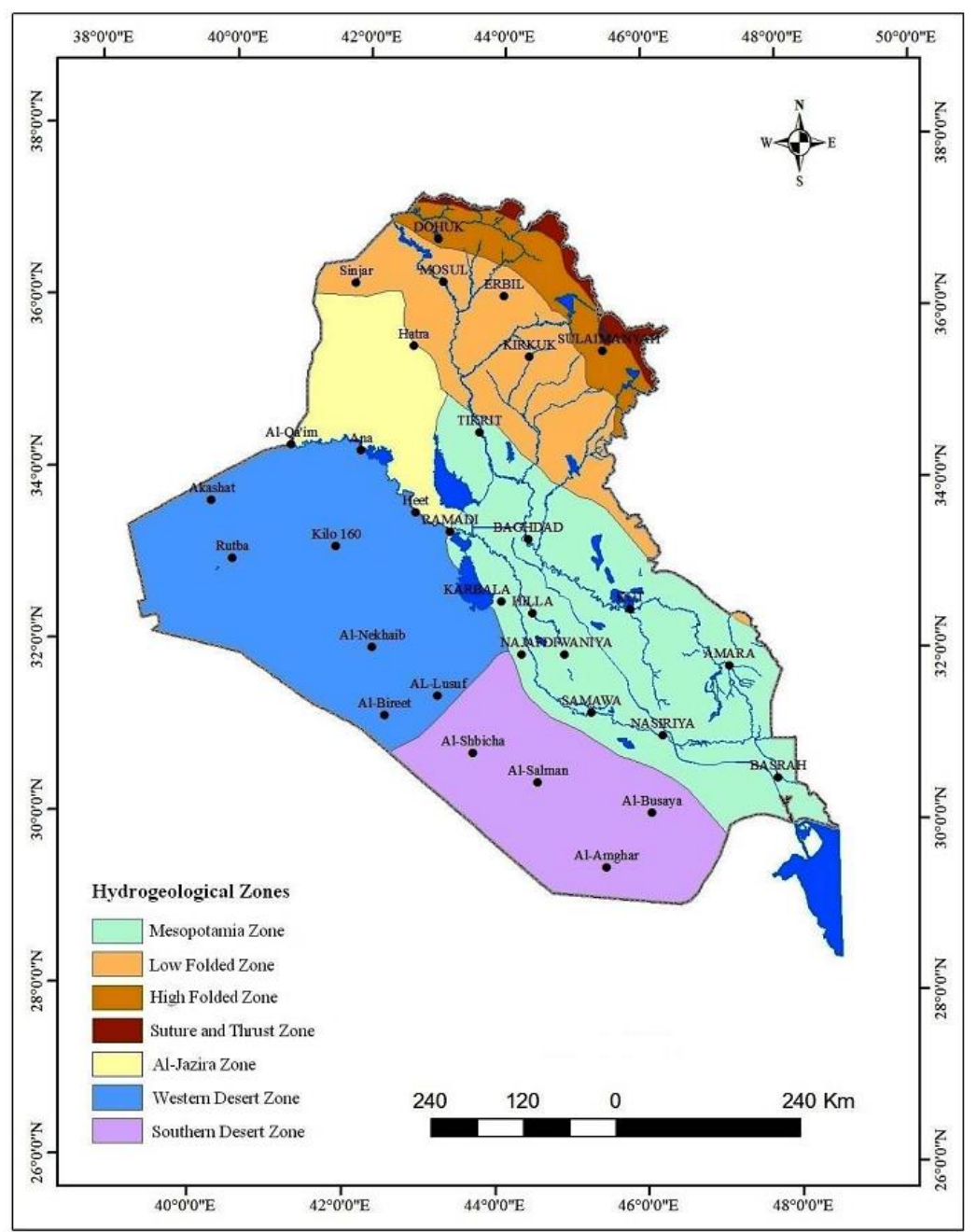

Figure 5: The main hydrogeological zones in Iraq (Al-Jiburi and Al-Basrawi, 2015).

1. Cretaceous-Tertiary limestone Aquifers, that are characterized by dense fractures and fissures, which represent the secondary porosity in the formations of Tayarat, Akashat and Ratgha, in the faraway west of Western Desert (west of Rutba).

2. The Permian Sandstone Aquifers, are represented by the formations of Al-aqraa and Beer Al Rah in the Al Rutba Sub-zone in the west of the Western Desert, to the northeast of the aquifers mentioned in the first aquifer group,

3. Triassic-Cretaceous aquifer in limestone-sandy rocks with dense fractures and fissures, and these aquifers are existing in Molusa formations, Zur-Horan, Ubaid, Al-Hussainiyat, Amij, Muhaiwir, Sakar, Nahr Umar, Rutba-Masaad, Harthah, Tayarat, within the Rutba Sub-zone, to the southeast of the aquifers mentioned 
in the first aquifer group.

4. The limestone aquifers in Paleogene - Neogene, which are found in the formations of the Euphrates, the Kirkuk group, and the formation of laurel, and extend from the Western Desert to the Southern Desert, within the areas of Rutba and Salman Subzones, to the west of the Euphrates River and to the east of the previous three mentioned aquifer groups.

5. Karstified Paleogenic Carbonate Aquifers, that are characterized by dense fractures and karst gaps that are found in the formations of Umm Erdhumah, Jil and Dammam, in the Salman area in the southern Desert.

6. Sandstone aquifers and masseuses in the Miocene -Pliocene, which are found in the formations of Ghar, Zahra and sedimentary deposits of Nakheb subsidence, in the subzone of Rutba and Salman zone, in the western and southern Desert.

7. Mio-Pliocene Dibdiba sandstone aquifers, within the Salman Zone in the Southern Desert, the faraway south of Iraq.

8. Gravel sand fans aquifers, in Wadi Al-Batain in the southern desert within the Mesopotamian zone, in the faraway south of Iraq.

9. Karst aquifers in the gypsum and limestone rocks in the middle Miocene within Fatha formation in the subzone of Ga'ara in northwestern of Iraq.

10. The aquifers of the flood plain, within the sandy deposits in the Quaternary, in central and southern Iraq, in the Mesopotamian Foredeep.

11. Gravel and sand deposition aquifers within the quadrilateral river fans, along a series of Makhoul and Hamrin folds, in the central and southern Iraq, along the eastern borders of the Foothill and Mesopotamian.

12. Sandstone aquifers within the Injana (Miocene-Pliocene) and Muqdadiya (Pliocene) formations in the north and northeast of Iraq, within the foothill zone.

13. The conglomerates aquifers in the Quaternary and Pliocene within the formation of Bai Hassan, in the synclines in northeastern Iraq, within the range of foothill and parts of the high fold zone.

14. Limestone rock aquifers between the Mesozoic and Triassic, and igneous and metamorphic rocks, which are characterized by the intensity of fractures and fissures, in the mountainous areas within the High Folded Zone, northern and eastern Iraq.

15. Some comprehensive studies indicated that several groundwater aquifers extend or (share) more than one of the groups of aquifers that mentioned within this classification, and some of these area significantly important, in which some of them illustrated by (Al-Fatlawi, 2010), which is divided the extend of the Umm Rudhuma aquifer (Mentioned in group 5 of this classification) west of the Euphrates in the southern desert and the eastern part of the Western Desert into two parts. The first part is a confined aquifer that extends along the West Bank of the Euphrates and extends from Basra in the south to the easternmost part of the Western Desert. While, the second part, which represents the unconfined aquifer, it will be on Stripe shape that extend parallel to the first part and to the west of it, and these two aquifers of the most important invested aquifer extensively in the southern desert and east of the Western Desert. 


\subsection{Quality of Groundwater in Iraq}

The groundwater quality varies across the country. As explained by Sabbar et al, (2020), the most accessible, highest producing and highest quality aquifers are found in the north-east. In this zone, there is high rainfall and the concentration of total dissolved solids in the groundwater is generally very low. In arid and semiarid areas like Iraq, the chemical composition of groundwater in the shallow subsurface zone depends on the quality of the recharge water and the depth of the water table. Sodium and chloride contents generally increase with depth, and in deep-seated zones, sodium, calcium and chloride brines are prevalent. These vertical chemical changes in groundwater composition are accompanied by a general depth-related increase in salinity.

The groundwater classes in the upper recharge areas are generally of low salinity Bicarbonate water type, especially in the north and northeast of Iraq and pouches in Sinjar and the western and southern desert, while it does not penetrate and move rapidly towards sub-surface to change its quality and increase its salinity (Figure 7). 


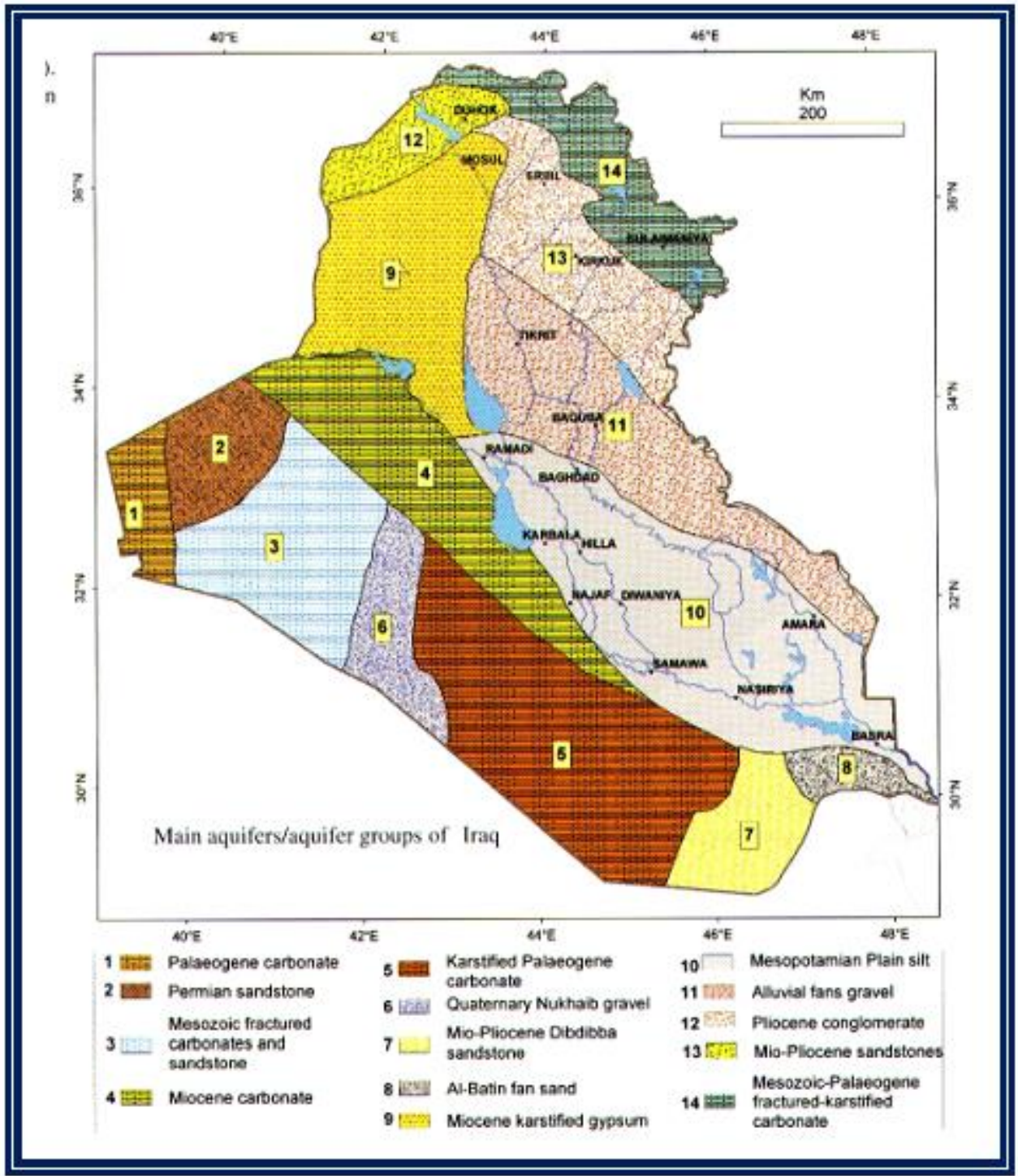

Figure 6: The Major groundwater aquifers in Iraq (Krasny et al, 2006).

In the Western Desert, the water quality is generally Bicarbonate-Chloride water type, but in the middle of this desert is Bicarbona-Sulphate water type, and this results from its interaction with carrying rocks in the geological formations that storing groundwater. A more detailed map in the western part of the Western Desert developed by (UN-ESCWA and BGR, 1999). Groundwater in the part adjacent to the Jordanian border is a sulfate waters of low salinity, while in the northeastern part is a chloride of low salinity as well, and the waters of the southern and southeastern parts are fresh and bicarbonate, (Sabbar et al, 2020).

The groundwater in the area of the Low Folded Zone and Foothill is a bicarbonateSulphate water type, and this results from its interaction with gypsum rocks or 
gypsum-rich rocks as a binder, especially in the formation of the Fatha, which leads to a deterioration in the groundwater quality.

Generally, in the Southern Desert and central and southern region of Al-Jazira and the strip adjacent to the Iranian border in eastern Iraq, the groundwater will be Sulphate water type and this is due to the presence of gypsum rocks in the aquifer rocks or rocks through which the groundwater passes during its vertical or horizontal movement, moreover in the narrow zone of the upper Al-Jazira near the Sinjar Mountain will be the Chloride-Sulphate water type, and the Mesopotamian area represents the collective area of salts that washed out by groundwater in Iraq, during its movement towards the Downstream areas, and it often contains high concentrations of a Chloride water type, (Sabbar et al, 2020).

An assessment of the suitability of groundwater for agricultural purposes was made in the hydrogeological region of Iraq based on the Richard classification (1954) by (Al-Jiburi and Al-Basrawi, 2015), this evaluation was represented in Figure 7. The map reflects the variation in water and soil salinity, in addition to assessment of groundwater for irrigation purposes. This evaluation was developed in combination with the soil properties in the various hydrogeological regions by (Buringh, 1960). Accordingly, the groundwater is suitable significantly for agricultural purposes in the northeastern borderline of Iraq and is good and suitable for all crops and soils in the High Folded Zone.

While, in the Low Folded zone, the western part of Western Desert, and the north part of the Southern Desert, their use will be permissible. In the eastern part of the Western Desert and southern part of Southern Desert, and the ranges of Al-Jazira, the Foothill, upper Mesopotamian and eastern Iraq from Badra to the south of Messan and Safwan-Zubair, their water will be of low quantity, but they are used for strategic crops that tolerate salinity (Sabbar et al, 2020).

However, in the southern part of the Mesopotamian, the groundwater is of very low quantity and is not suitable for irrigation for all types of crops.

\subsection{Hazard on Groundwater quality change in Iraq}

Approximately $30 \%$ of Iraq's population has access to a sanitary sewer system and, of the 18 governorates, only ten have wastewater treatment facilities. According to COSIT (2011), access to sewer systems tends to be concentrated in urban areas where wastewater treatment facilities are available. This means that most rural areas do not have access and therefore resort to alternate means of discharging sewage (e.g., underground septic systems or discharging untreated waste into channels or rivers).

Baghdad's sewer network serves approximately $78 \%$ of the governorate, but for the remaining governorates that have treatment facilities, the extent of the sewer network covers less than $30 \%$ of the area, and in some cases, less than $10 \%$, (COSIT, 2011). The public health implications of these conditions are dire, exposing the population to pathogens and other contaminants that enter the water supply as untreated wastewater drains to freshwater sources. Between 2007 and 2012, at least three outbreaks of cholera were reported, and for each of the years 
between 2007 and 2010, more than 44,000 cases of typhoid, bacillary dysentery and hepatitis B were reported (UNESCO, 2014). In 2012, at least four people died due to cholera outbreaks in northern Iraq (WHO, 2012).

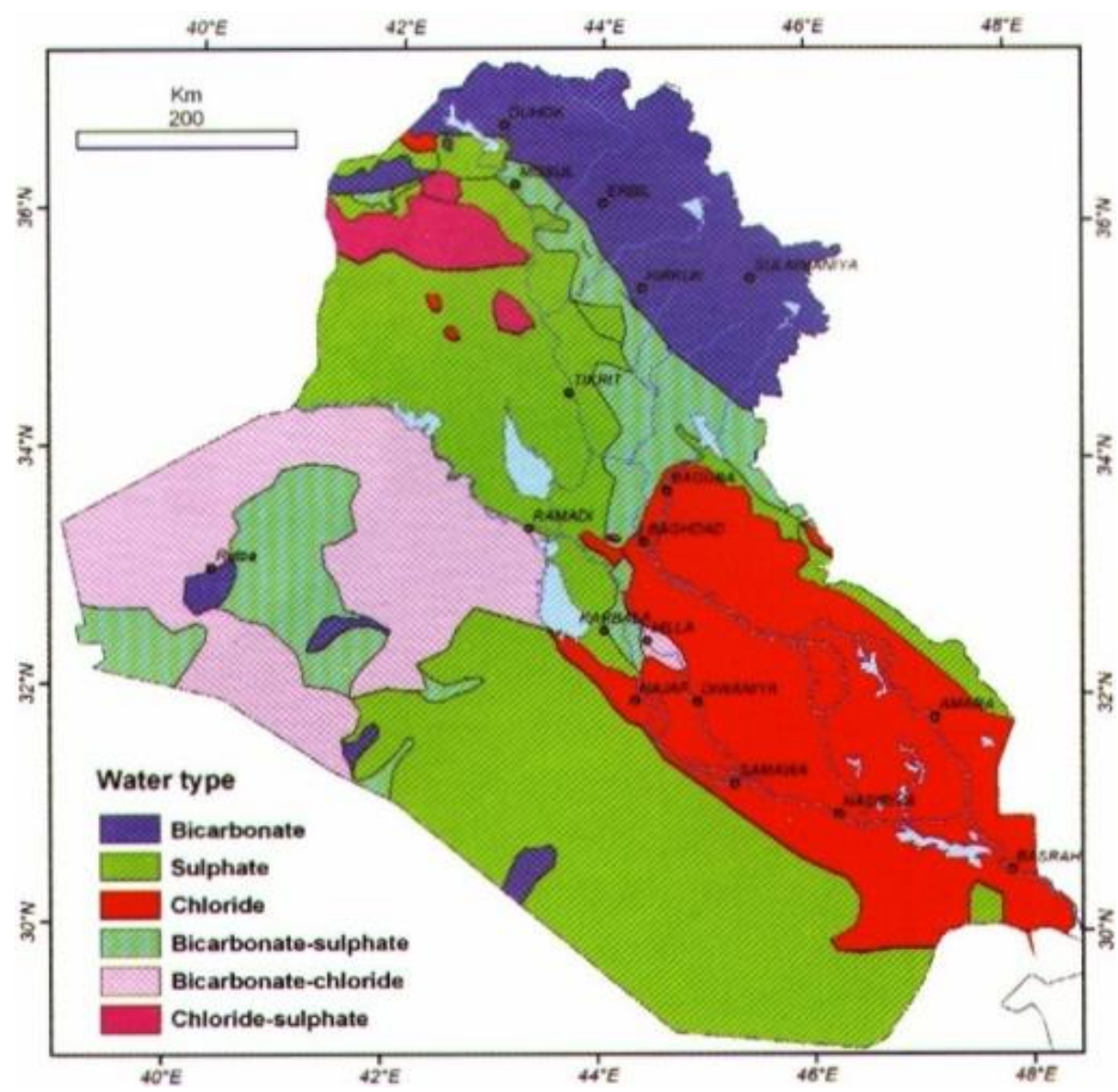

Figure 7: Classification of groundwater quality near to the earth surface in Iraq (Krasny, 2006).

Three decades of war followed by more than a decade of sanctions and the associated crumbling of basic infrastructure has been disastrous for Iraq's environment. A reduction in stream flows, pollutants in freshwater systems, polluted and declining groundwater tables, degraded ecosystems, habitat loss and a reduction in biodiversity has caused damage across the country. It is estimated that the cost of environmental degradation is between $4.9 \%$ and $8.0 \%$ of the annual gross national production (MEI, 2013). Therefore, is widely acknowledged that there is an urgent need for the adoption of water quality management measures in Iraq, particularly related to groundwater. 


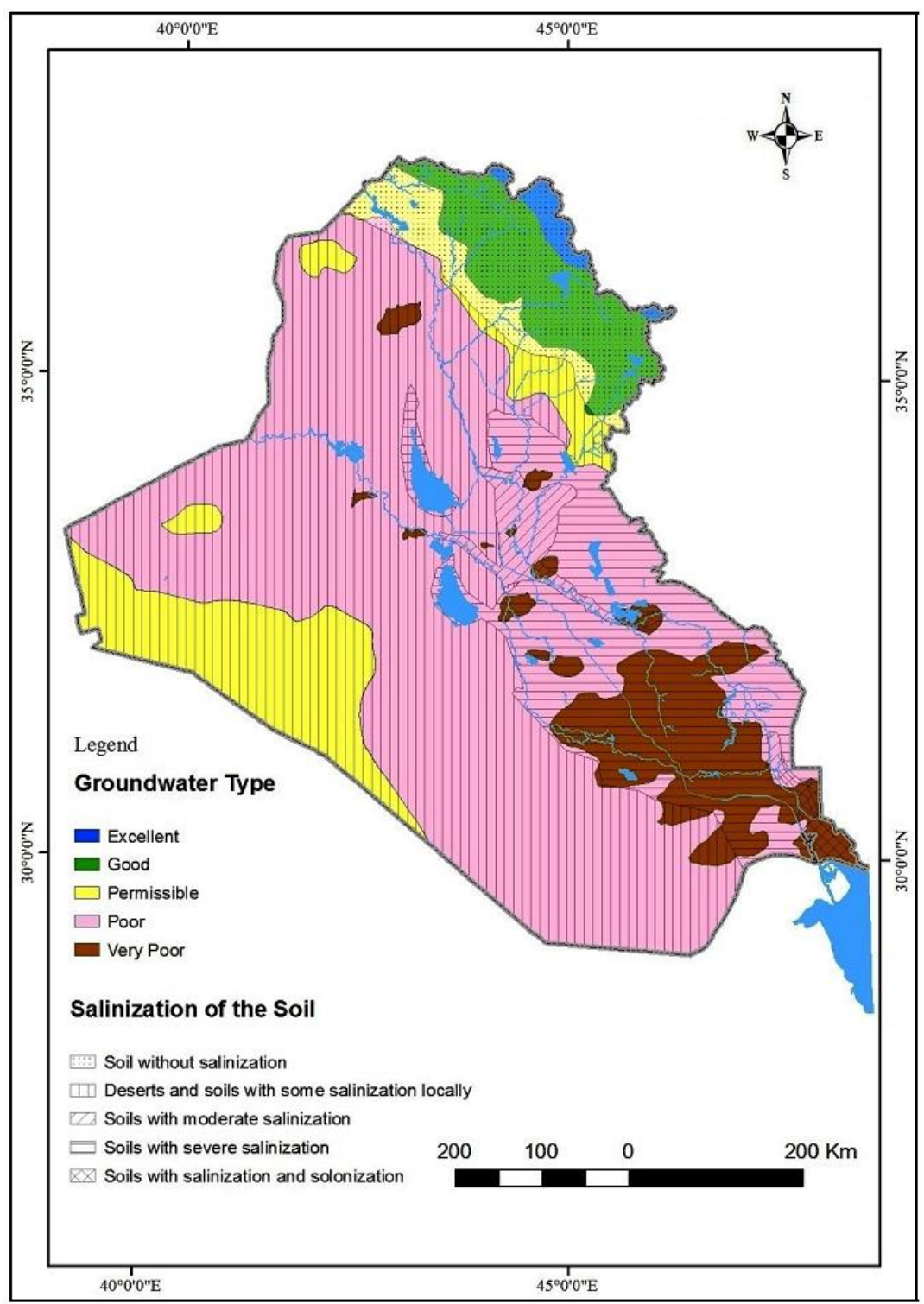

Figure 8: Groundwater suitability for irrigation purposes (Al-Jiburi and Al-Basrawi, 2015). 


\section{Effect of Water Quality Deterioration on Human and Environment}

\subsection{Dam Constructions}

The implementation of irrigation projects and construction of dams in the Tigris and Euphrates basins have had considerable influence on the society and the environment. According to Al-Ansari et al. (2018), the constructed dams in Turkey within the GAP project plans have a total storage capacity of $100 \mathrm{~km}^{3}$ while in Syria the reservoirs have a capacity of $16.1 \mathrm{~km}^{3}$. Besides, these massive water bodies in an arid to semi-arid environment will increase the rate of evaporation. Hillel (1994) estimated the loss due to evaporation from the existing reservoirs on the Euphrates River to be $8 \mathrm{~km}^{3} / \mathrm{y}$, in which cause gradually increase in salinity and decrease the volume of flow.

In addition, filling the reservoirs of these dams had hard negative consequences on downstream riparian countries. Syria used to receive $29 \mathrm{~km}^{3}$ of water from the Euphrates River before 1990, while after 2000 dropped to about $2 \mathrm{~km}^{3}$ (Mageed, 1993). Likewise, Iraq was also affected with the flow of the Euphrates dropping from $29 \mathrm{~km}^{3}$ to about $4 \mathrm{~km}^{3}$ (about $90 \%$ reduction). As a result, agricultural lands in Syria and Iraq were reduced from 650,000 hectares to 240,000 hectares (AlAnsari et al., 2018). As far as the Tigris River is concerned, it is expected that 696,000 hectares of agricultural land will be abandoned due to the reduction of flow when Ilisu dam is put in operation, then Iraq will receive only $9.7 \mathrm{~km}^{3}$ (Alalaf, 2009). This has resulted so far in few incidents of high tension and friction between riparian countries when the reservoirs of dams were filled and resulting in tremendous decrease in the flow (Akanda et al, 2007; FAO, 2009c; Alsaka, 2014; Al Bomola, 2011).

Furthermore, Iran has so far diverted the water of almost all the valleys coming to Iraq inside the Iranian borders due to water shortage problems in Iran (Sharifikia, 2013, Al-Shaab, 2017, Proyect, 2018). Similarly, the water of Karun and Karkha Rivers were also diverted inside the Iranian borders. These rivers used to contribute 24.5 and 5.8 billion cubic meters (BCM) annually, respectively, (Abdullah, 2016). These caused increase of the salinity within the lower reaches of the Tigris River and Shatt Al-Arab River.

\subsection{Al-Tharthar Scheme}

Al-Tharthar lake is located between the Tigris and Euphrates Rivers at the middle of Iraq. Its water is saline brackish where the total dissolved salts concentration is about $2500 \mathrm{ppm}$ due to the dissolution of gypsum rocks forming its banks and floor. Its storage capacity is about $85 \mathrm{~km}^{3}$ with a surface area of about $2050 \mathrm{~km}^{2}$ and it is about $120 \mathrm{~km}$ long and with a maximum width of about $48 \mathrm{~km}$ (Figure 9) with a floor of $-3 \mathrm{~m}$, bellow the sea level (Sissakian, 2011). Since 1956, this depression has been used to store access water from the Tigris River during floods. The capacity of the canal that transfers water from the Tigris at Sammara barrage to AlTharthar reaches $9000 \mathrm{~m}^{3} / \mathrm{s}$. The remainder quantity of water is passed through 
downstream to Baghdad through that barrage. Later in the 1980's, this lake was used to back up the water shortages in both the Euphrates and the Tigris Rivers through a $28 \mathrm{~km}$ long canal. This canal splits into two branches: the first one is Dhir'aa Dijla which transfers water back to the Tigris River at Al Taji north of Baghdad, and Dhir'aa El-Furat which transfers water back to the Euphrates River (Figure 9). The mixing of Al-Tharthar lake brackish water with the river waters led to an increase of the salinity in these rivers.

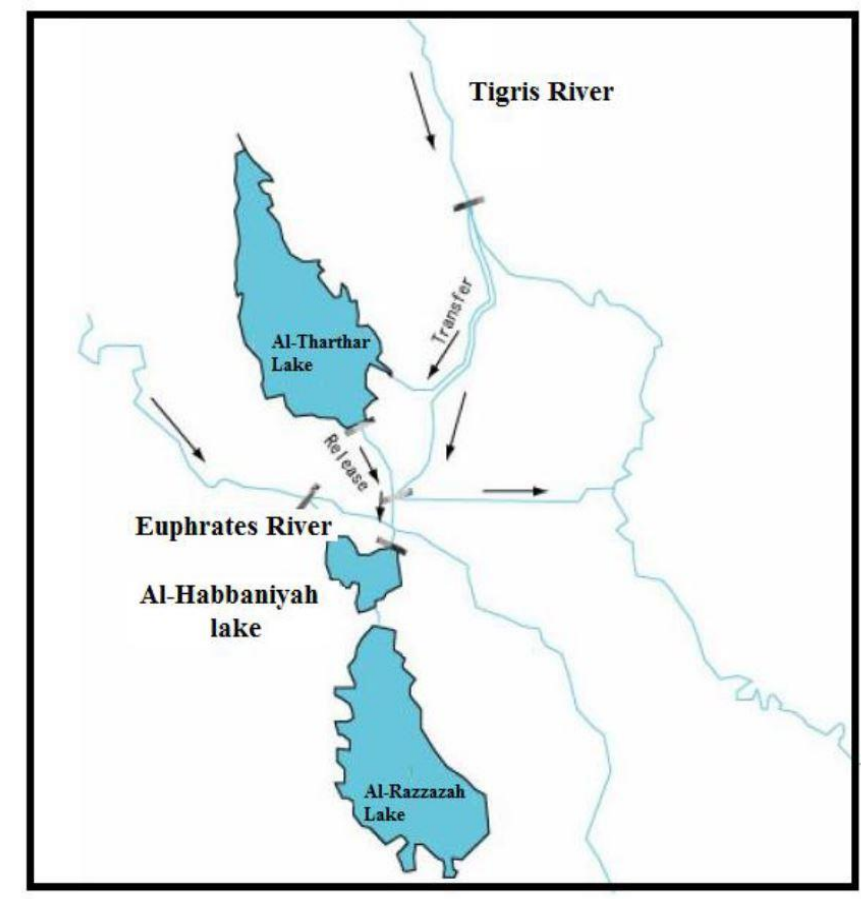

Figure 9: Diversion system between Tigris and Euphrates (Al-Ansari et al, 2018).

\subsection{Agriculture and Irrigation}

Because of high population growth rates and rapid development within the riparian countries, the governments tried to attain food self-sufficiency by implementing large and huge irrigation projects (Table 2). Consequently, agriculture became the largest water consumer in these countries where it reached 78, 88 and 73\% in Iraq, Syria, and Turkey respectively (FAO, 2009a, b, c). In addition, all riparian counties suffered from salinity-alkalinity and waterlogging problems caused by irrigation and insufficient drainage systems (FAO, 2009a, b, c). The return water flow from irrigation projects negatively affected the water quality particularly within the Euphrates basin (FAO, 2009 c).

In the southern part of Iraq, salinity problems were reported since Sumerian times. The water table in this area is high and over irrigation brings it up to the roots of the crop. This has destroyed the crop in large areas in Iraq and to overcome this 
problem, it will take several years (Schnepf, 2003).

Irrigation is often the largest user of fresh water and may quickly experience supply gaps in years that are relatively dry, partly because it has a lower supply priority compared to the public water supply. Based on the model results, Missan experienced irrigation shortages almost continuously, and the demand was unmet 99 per cent of the time (in the period 1998-2018), while Thi-Qar and Al-Muthanna experienced shortages only in relatively dry years $(1999,2000,2001,2008,2009$, 2012, 2014, 2017 and 2018). During these dry years, shortages could be considerable, as the low supply/demand ratios show. Babil and Wassit, the other two governorates of Iraq with a significant percentage of irrigation land, did not experience irrigation water shortages, (IOM,2020).

Table 2: Water consumption within riparian countries of Tigris and Euphrates

Basins (FAO, 2009a, b, c).

\begin{tabular}{|c|c|c|c|c|c|}
\hline \multirow[t]{2}{*}{ Population } & \multirow{2}{*}{$\begin{array}{l}\text { Cultivated } \\
\text { area (ha) }\end{array}$} & \multicolumn{4}{|c|}{ Water withdrawal (MCM) } \\
\hline & & $\begin{array}{c}\text { Irrigation } \\
\text { and } \\
\text { livestock }\end{array}$ & Municipalities & Industry & Total \\
\hline \multicolumn{6}{|c|}{ Iraq } \\
\hline $\begin{array}{c}28,807,000 \\
(2005)\end{array}$ & $6,010,000$ & $\begin{array}{l}52,000 \\
(78 \%)\end{array}$ & 4,300 & 9,700 & $\begin{array}{l}66,000 \\
(2000)\end{array}$ \\
\hline \multicolumn{6}{|c|}{ Syria } \\
\hline $\begin{array}{c}19,043,000 \\
(2003)\end{array}$ & $5,742,000$ & $\begin{array}{l}14,669 \\
(88 \%)\end{array}$ & 1,426 & 595 & $\begin{array}{l}16,690 \\
(2003)\end{array}$ \\
\hline \multicolumn{6}{|c|}{ Turkey } \\
\hline $\begin{array}{c}73,193,000 \\
(2003)\end{array}$ & $26,606,000$ & $\begin{array}{l}29,600 \\
(73 \%)\end{array}$ & 6,200 & 4,300 & $\begin{array}{l}40,100 \\
(2003)\end{array}$ \\
\hline
\end{tabular}

\subsection{Wastewater}

In Iraq, 14 cities have wastewater treatment plants out of 252 cities with a capacity of $350,000 \mathrm{~m}^{3} /$ day which serve $8 \%$ of the population (Al-Ansari et al., 2018). Most of the sewerage systems need replacement, rehabilitation and upgrading and about $70 \%$ to $83 \%$ of the sewage water is directly discharged to the rivers (World Bank, 2006; Geopolicity, 2010).

About $26 \%$ of the population in Iraq are served through public sewerage net-works while $50 \%$ through septic tanks and $7.1 \%$ and $15.1 \%$ through covered and open drain respectively (Al Bomola, 2011). Toilets are connected to the sewer system or 
septic tanks (MICS, 2011) and most of these do not function properly where there is an overflow of effluent to the environment (UNICEF, 2003). About 83\% of the wastewater is directly discharged to the rivers (Geopolicity, 2010). Wastewater is discharged to rivers from industrial factories as well where there are more than 137 factories on the banks of the rivers in Iraq (Al Bomola, 2011, Alsaka, 2014).

\subsection{Waste of Wars}

Unluckily, Iraq went through two devastating wars in 1991 (Gulf War I) and 2003 (Gulf War II) during which new weapons were used called Depleted Uranium (DU). In the second war, the quantity of DU bombs used was five times more than what was used in the first war. More than 1100 to 2200 tons of DU were used in 2003 (Zwijnenburg, 2013). The targets that were bombed with DU weapons were spread all over Iraq (Figure 10).

During the two wars, civilian facilities (power plants and refineries) were also bombed. Legacy of the contaminants are either transient or long lived (Figure 11). During these wars, the Iraqi troops left plenty of ammunitions and poisonous gas in the marshy area of south Iraq (Sluglett, 2003; Tkachenko, 2003). As stated by UNEP (2003), there are about 300 polluted locations in Iraq of various types (Table 3). 


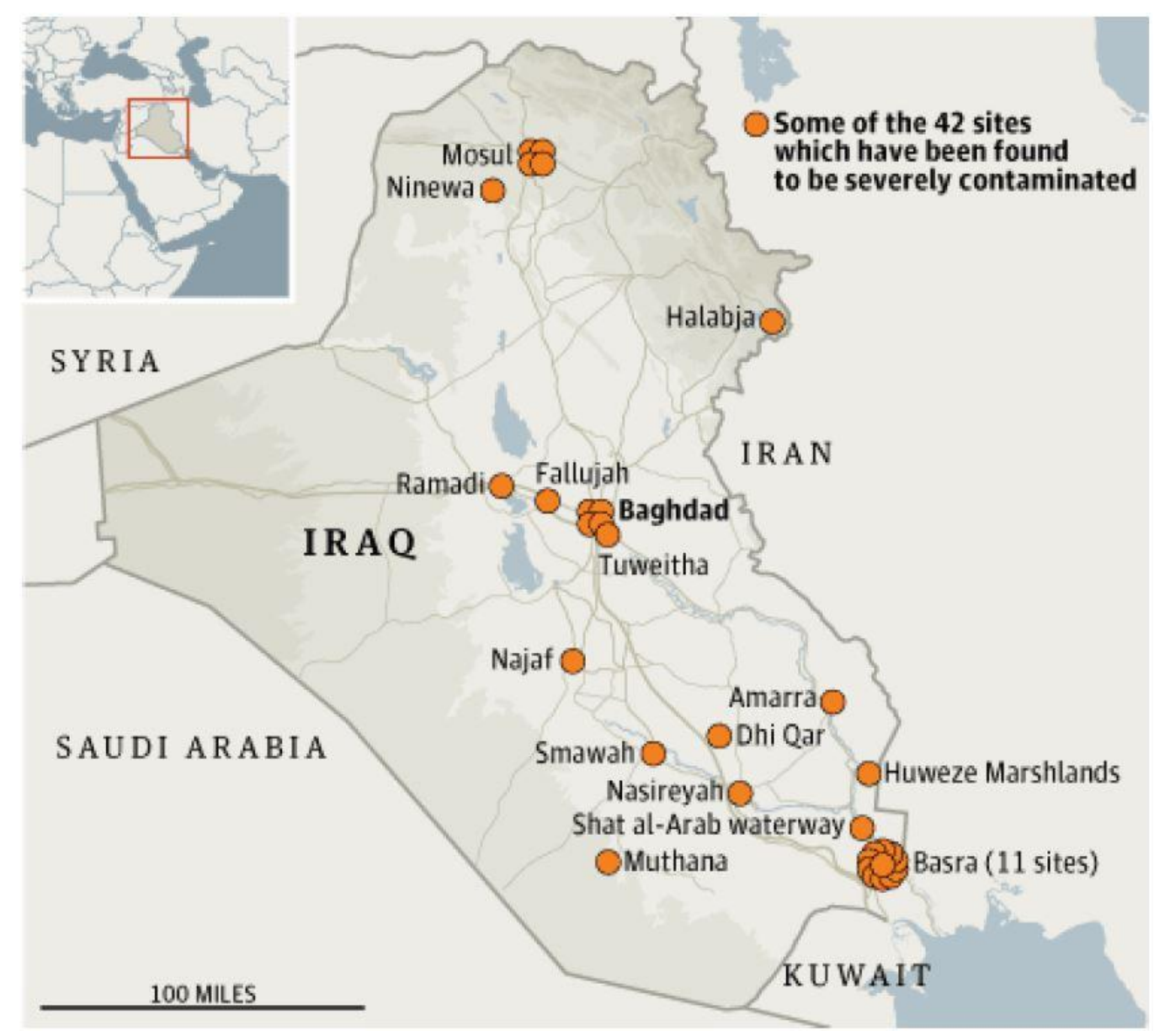

Figure 10: Contaminated sites in Iraq with DU (Chulov, 2010)

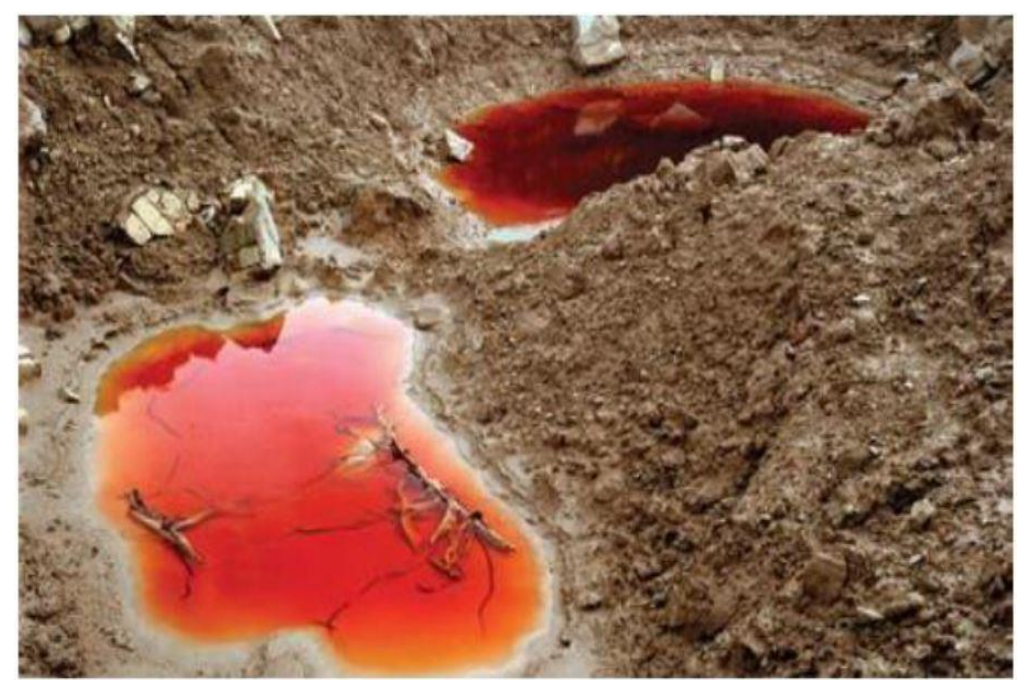

Figure 11: Unburnt trinitrotolluine (TNT). Iraqi Army ammunition storage depot, Missan Governorate, south eastern Iraq, 2004 (Zwijnenburg, 2013). 
Table 3: The hot-spot sites and oil polluted sites in Iraq (UNEP, 2003).

\begin{tabular}{|l|c|}
\hline \multicolumn{1}{|c|}{ Type of Industry } & No. of sites \\
\hline Conventional Army Industry & 38 \\
\hline Oil production and export & 15 \\
\hline Oil and Chemical refining & 6 \\
\hline Mining & 2 \\
\hline Agriculture/Pesticides & 1 \\
\hline Steel & 1 \\
\hline Cement & 16 \\
\hline Chemicals (excluding arms-related) & 6 \\
\hline
\end{tabular}

\subsection{Climate Change}

Riparian countries of the Tigris and Euphrates basins are extremely concerned by climate change (Al-Ansari, 2013, 2016; IPCC, 2007). Analysis of rainfall long term records show that the annual average rainfall is decreasing with time, this will have serious consequences on the river basins, (Al-Ansari et.al., 2014d). As an example, $71 \%$ of the water of the Euphrates River is from precipitation in Turkey (UNDP, 2011). Decrease of rainfall is associated with increase in temperature (Al-Ansari, 2013). These trends suggest more evaporation and there will be more drought periods. In addition, intensive rainfall events will take place. This implies negative consequences where groundwater recharge will be decreased due to the decrease in infiltration rates in short periods of time. As such rainfall events takes place after drought periods, then sediment erosion will be increased tremendously. This will minimize the land production due to intensive soil erosion and it will decrease the storage capacity of reservoirs.

Other implications of climate change are dust storms (Figure 12), this will lead to aerosol pollution which will change the properties of the clouds and reduces precipitation. In the past few years, Iraq and neighboring countries experienced plenty of dust storms. The reduction of flow of the Tigris and Euphrates Rivers, the drying of marshes and military operations had also enhanced the formation of these storms.

As predicted by (Maddocks et al., 2015), indicates that the countries of the Middle East will be most water stressed by 2040. All countries within the Tigris and Euphrates basins lie within this category. Iran will have relatively the maximum water stress followed by Iraq, Syria, and Turkey (Maddocks et al., 2015). 


\subsection{Solid Waste}

As stated by (Al Bomola, 2011), enormous quantities of solid waste are generated in all riparian countries. The waste is of different types and origins (Table 4). These wastes are not dumped in properly designed landfills. Therefore, they end up in roadsides or floating on surface water (Al Bomola, 2011). In addition, clinical waste which is supposed to be treated and disposed and burned in special medical incinerator is also mixed with domestic waste. This is since most of hospitals in Iraq either do not have incinerators or in those hospitals that which have them $90 \%$ of these incinerators are not functioning (Al-Ansari et al, 2018).

Table 4: Types of solid waste (Al Bomola, 2011).

\begin{tabular}{|l|l|}
\hline Type of solid waste & \multicolumn{1}{c|}{ Most materials } \\
\hline Refuse & $\begin{array}{l}\text { Commercial, industrial and residential } \\
\text { waste }\end{array}$ \\
\hline Garbage & Food waste and organic material \\
\hline Rubbish & Tin cans, glass, paper, wood cloth grass \\
\hline Ashes & $\begin{array}{l}\text { Resulting from coal for cooking and } \\
\text { heating }\end{array}$ \\
\hline Trash & Tree, branches and big boxes \\
\hline
\end{tabular}

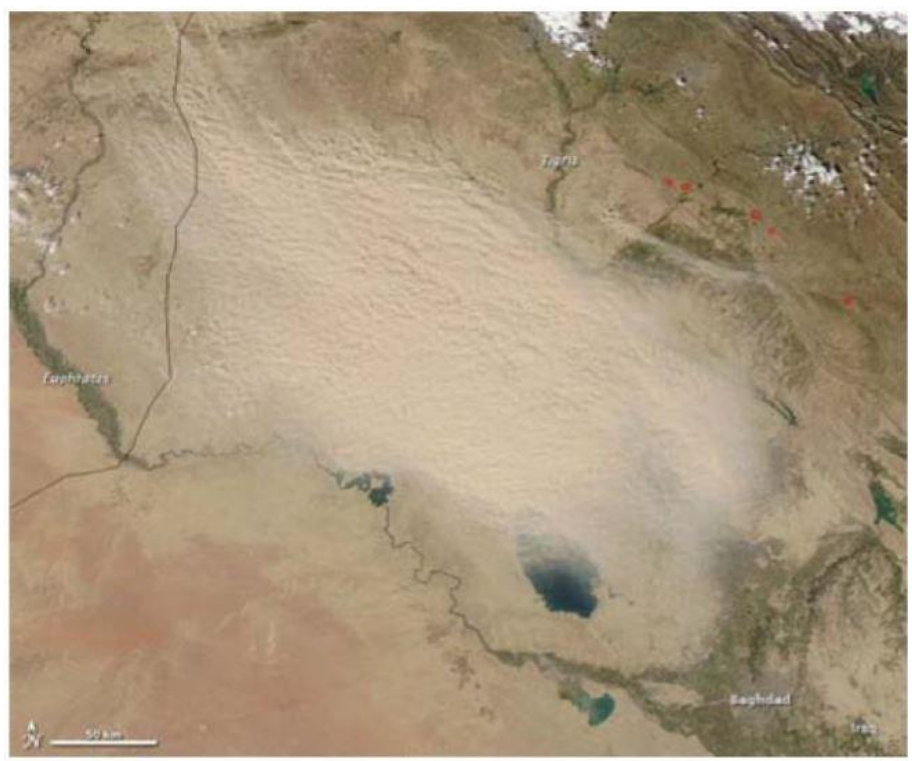

Figure 12: Aerial view of a dust storm. Note it had started just in the northwestern borders of Iraq. (The Moderate Resolution Imaging Spectroradiometer (MODIS) on NASA's Aqua satellite captured this natural color image on March 3, 2011). (After Sissakian et.al., 2013). 


\subsection{Population Growth}

Riparian countries of the Tigris and Euphrates basins including Iran where some of the Tigris tributaries are located inside its borders are highly populated (Table 5) (Worldmeters, 2018). Most of the population particularly in Syria and Iraq live in narrow areas near the banks of the rivers. The high population growth rates in Syria and Iraq will increase the future demand for water where the population will be more than doubled in 2050 (Table 4) (Wikipedia, 2018; Population Reference Bureau, 2015). This will increase the demand on water and increase water consumption. Therefore, the probability of water pollution will increase as well as the stress for water (Figure 13, UN Water, 2016).

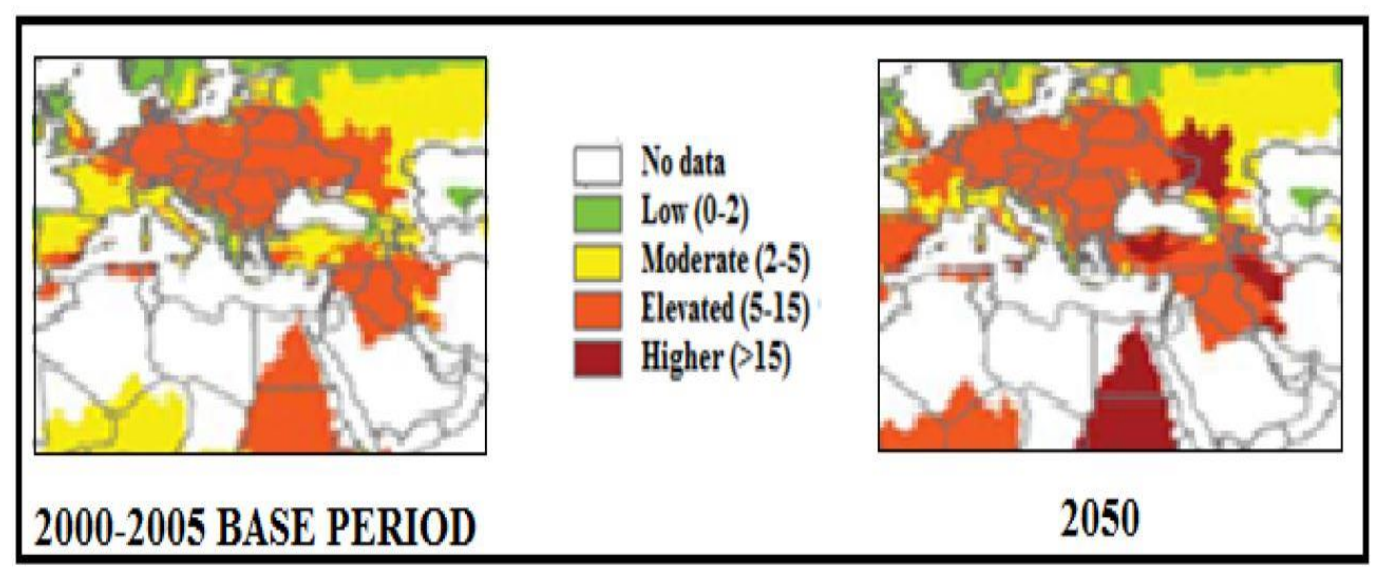

Figure 13: Water quality risk indices for major river basins during base period (2000-2005) compared to 2050 (Modified from UN Water, 2016).

Table 5: Present and future Populations in countries within the Tigris and Euphrates basins, (Al-Ansari et al., 2018).

\begin{tabular}{|c|c|c|c|}
\hline \multirow{2}{*}{ Country } & Population & \multicolumn{2}{c|}{ Expected Population } \\
\cline { 2 - 4 } & 2018 and Yearly change & $\mathbf{2 0 3 0}$ & $\mathbf{2 0 5 0}$ \\
\hline Iraq & $39,339,753^{*}$ & $54.071 * *$ & $83.652^{* *}$ \\
& $2.78 \%$ & $53.4 * * *$ & $76.5^{* * *}$ \\
\hline Iran & $82,011,735^{*}$ & $88.559 * *$ & $92.219^{* *}$ \\
& $1.05 \%$ & $90.2 * * *$ & $99.3 * * *$ \\
\hline Syria & $18,284,407 *$ & $28.647 * *$ & $34.902^{* *}$ \\
& $0.08 \%$ & $26.1 * * *$ & $10.4 * * *$ \\
\hline Turkey & $81,916,871^{*}$ & $87,717 * *$ & $95,819^{* *}$ \\
\multicolumn{2}{|c|}{$1.45 \%$} & $88.4 * * *$ & $93.5 * * *$ \\
\hline *Worldmeters, Countries in the world by population (2018) \\
http://www.worldometers.info/world-population/population-by-country/ \\
**Wikipedia, List of countries by future population (United Nations, medium fertility variant) \\
https://en.wikipedia.org/wiki/List_of_countries_by_future_population_(United_Nations,_medi \\
um_fertility_variant) \\
***Population Reference Bureau, 2015, World Population Data with a special focus on \\
women's http://www.prb.org/pdf15/2015-world-population-data-sheet_eng.pdf \\
\hline
\end{tabular}




\section{Development of the Iraqi Water Quality Index (Iraq WQI)}

Since of the importance of water for human life and the need to monitor temporal and spatial changes, researchers in many countries of the world developed a number of water quality indices for their countries to classify the quality of water for different uses, which used in the Iraqi studies, although they were designed for different water in other countries.

There is a need to develop a general Iraqi Water Quality Index (Iraq WQI) to monitor surface water and groundwater qualities and classify it into five categories, very good, good, acceptable, bad and very bad, in terms of suitability for domestics, irrigation and agriculture depending on the Iraqi and WHO standards for drinking water. Note that this water will be subjected to purification and chlorination processes.

The WQI makes it easier to understand water quality issues by integrating and expressing complex data with a single number or word to describe the state of water quality that is clear and understandable to everyone and even to non-specialists of people, ministries and departments interested in water to maintain the sustainability and safety of surface water resources.

Some statistical techniques, experts' advice, literature reviews, and authors' experience were used. The principal component analysis (PCA) method and the modified Delphi method were used to select the most influential water quality parameters and their relative weights.

In the modified Delphi method, the physical and chemical determinants of water quality involved in the derivation of the index are selected according to the opinion of a number of Iraqi engineers and water experts who are polled by means of questionnaires that distributed to them.

The experts by their opinions selected the parameters by assigning their weights (numbered 1 to 5) depending on their importance and their impact on water quality. The quality curves of selected parameters were drawn to calculate the WQI scores basing on the water quality standards depending on their effect on water quality in order to reflect the specific characteristics of the Iraqi waters. The Iraq WQI was applied to the Tigris River within Baghdad as a case study and for some sites on other Iraqi rivers, and gave acceptable results.

The index development process can be summarized in the following steps:

1. Water quality parameters selection.

2. Assign Weights and determine the relative weights of the parameters.

3. Derivation of the sub-index functions for all selected parameters and plotting their curves.

4. Aggregation of Sub-indices and completion of the index derivation.

5. Then it will be converted into Windows and an Android application to be accessible to everyone.

Water quality are measured by the physical, chemical and biological criteria for water quality, such as temperature, turbidity, nitrate concentration, chloride concentration, conductivity, phosphate, cadmium, zinc, number of bacteria and 
oxygen biological demand.... etc

The interpretation of the numbers we get when measuring the water quality parameters is difficult even for experts and requires an explanation. Therefore, efforts have been directed towards the method of the calculation of the Water Quality Index (WQI), which facilitates the interpretation of the data obtained from the measurement of water parameters because we finally get one number (from 0 to 100 ) or one word (good, acceptable, bad, for example) and this is easy to understand even to the non-specialist.

Another characteristic of the WQI is that it is useful to track changes in the quality of water that occurs naturally over time or due to pollution, as well as to compare water conditions in different water bodies.

Many countries have developed their own water models and there are some Iraqi attempts on the subject. The attempts to classify water according to their suitability for different purposes are due to the mid-20th century and Horton (1965) is the first to suggest an index to water quality.

The WQI is a mathematical tool to convert the large data about water quality to a numerical value or one word that expresses the quality of water based on national and global standards (physical, chemical and biological) and the extent of deviation from them. The WQI can be used in environmental assessment through which the large quantities of water quality data can be converted into a single value that is clearly expressed the state of water.

Brown (1970) suggested that each parameter should be given a certain weight as important, resulting in the US National Sanitation Foundation NSF-WQI.

One of the most popular indices is the Canadian Water Quality Index (CCME) and the Oregon Water Quality Index (OWQI).

The benefits and uses of water quality indices can be summarized as follows:

- Comparing water quality from different sources, therefore deciding the appropriate use of the water resource concerned.

- Making policy choices more objective and less subjective.

- To define the difference in conditions before and after the implementation of the regulatory policy or legislation.

- To give an integral image of the overall quality of the source to make it easier for non-technical stakeholders to understand.

The multivariate statistical techniques were used to assist in water quality monitoring, formulating a rapid response to water pollution. The principal component analysis (PCA) is a multivariate statistical technique analytical method commonly used in the scientific community, since it allows to reduce the dimensionality of a data set while maintaining the characteristics of variables that contribute most to this variation.

There have been several attempts to develop general water quality indices for assessing the quality of the surface water. The Rand Corporation developed the Delphi technique to integrate expert opinions without the adverse effects of group response, using a series of questionnaires. The anonymity of individual responses, 
statistical analysis of responses, and increasingly validated feedback are important features of the method.

In the process, panel members are presented with response patterns learned during the previous round, allowing them to display all respondents' overall opinions, and if appropriate, they are asked to rethink their earlier responses. The process is ongoing until a desirable degree of consensus is gained between the respondents. The problems facing the water sector in Iraq are the lack of rain due to climate change, population growth along with increased consumption, and the neighboring countries' control on the rivers shared with Iraq, the other important problems are the increase in pollution and salinity levels, especially in the south of the country. There is no specific water quality index for Iraqi waters, and the use of other indices designed for the waters of other countries will not be accurate and will not give real results.

\subsection{Methodology of the Water Quality Index}

The general approach for creating an index of water quality can be summed up in the following four steps:

- Selection of suitable water quality parameters.

- Weight assignment of the selected parameters.

- Development of the sub-indexes' functions by the transformation of concentration of parameters into mathematical equations.

- Aggregation of sub-indices to construct the index.

In this study, in addition to the authors' experiences and information from previous studies, two statistical methods were used for developing the index. The first statistical method is the principal components analysis (PCA), and the second is a modified Delphi method in the survey of expert opinions.

This is the final index formula that was reached:

$$
\begin{aligned}
\text { Iraq WQI }= & {[(-0.019 \text { TDS }+84.587) \times 0.2] } \\
& +[(-0.006 \mathbf{T C}+86.231) \times 0.2]+[10 \mathrm{DO} \times 0.2] \\
& +[(-0.119 \mathbf{T H}+113.68) \times 0.15]+[-5.886 \mathbf{C O D} \\
& +99.846) \times 0.1]+[(-0.12 \mathbf{C l}+106.58 \times 0.15]
\end{aligned}
$$

Where:

(TDS) is the Total Dissolved Solids, by $\mathrm{mg} / \mathrm{L}$.

(COD5) is the 5 days Chemical Oxygen Demand, by $\mathrm{mg} / \mathrm{L}$.

(TH) is the Total Hardness, by $\mathrm{mg} / \mathrm{L}$.

(DO) is the Dissolved Oxygen, by $\mathrm{mg} / \mathrm{L}$.

(Cl-) is the Chloride ion by $\mathrm{mg} / \mathrm{L}$.

(TC) is the Total Coliform Bacteria by the Most Probable Number (MPN) in 100 $\mathrm{mL}$ (Figures 14,15). 

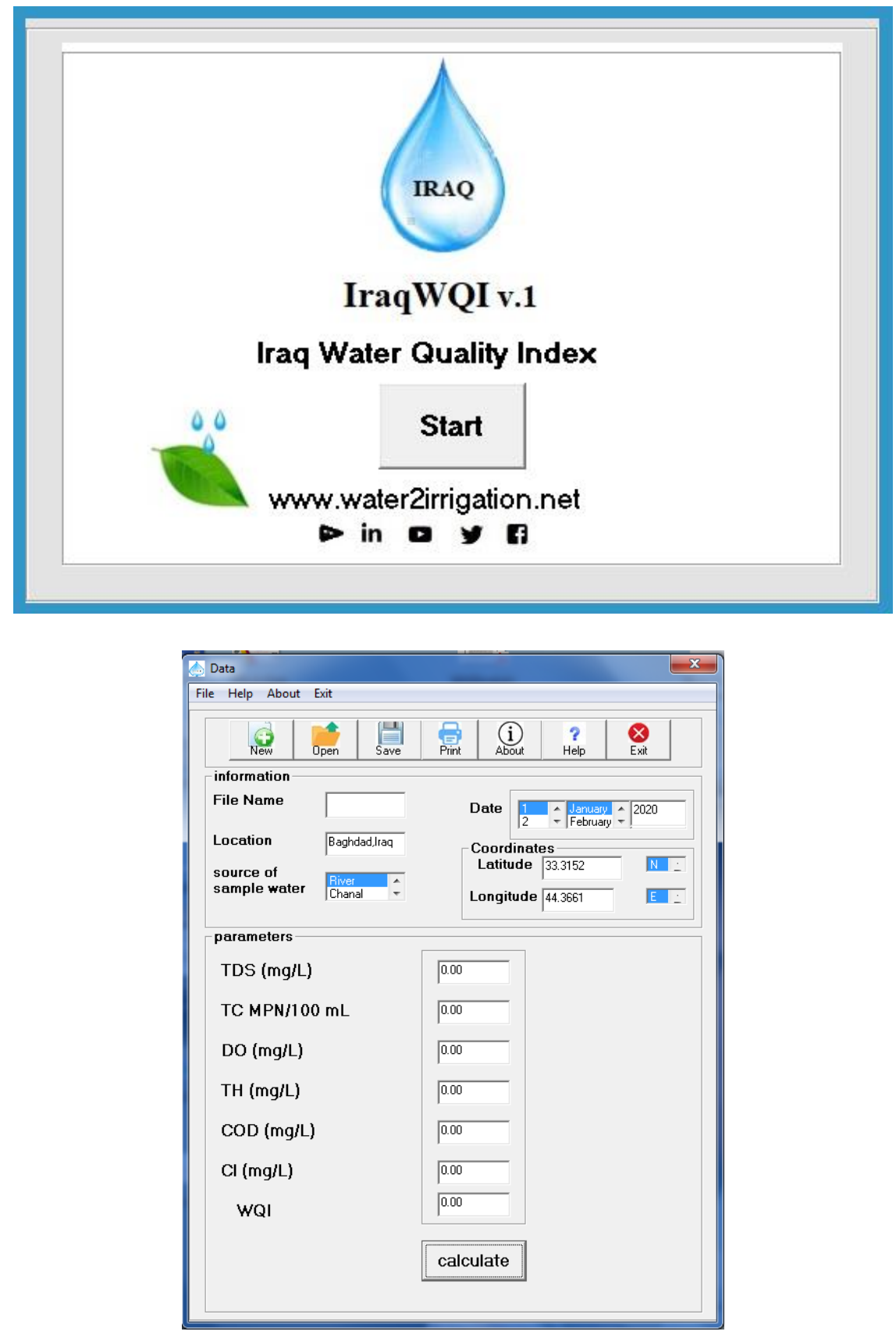

Figure 14: The Windows start and main menu of graphic user interface of the Iraq WQI for entering, calculating and saving results. 


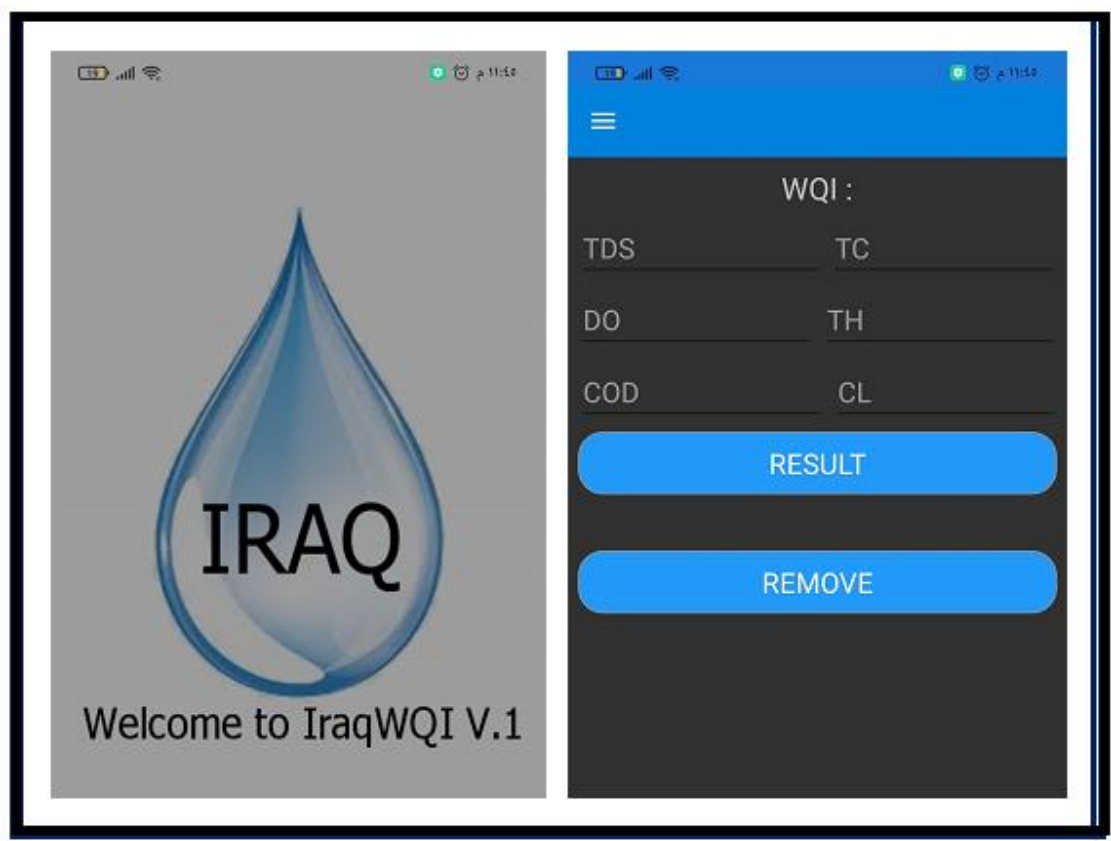

Figure 15: The Android icon and main menu of the user interface of the IraqWQI for entering and calculating the results.

\subsection{Recommendation}

1. The salinity percentage exceeds the permissible limits in the waters of many subsurface aquifers in the region of Al-Jazeera, Western and Southern Desert, the Middle Euphrates, and Eastern Iraq, except for the northern and northeastern basins of Iraq. However, some unlicensed organizations are still drilling wells in these aquifers, without taking hydrological studies recommendations into consideration to stop drilling deep wells to ensure that saltwater aquifers are not penetrated.

2. The groundwater is not suitable for domestic use in most parts of Iraq except the north and northeast, but there are some pouches somewhere in the Western and Southern Desert, which requires accurate investigation of these pouches in order to investing them in an optimal way.

3. Through some of groundwater qualitative characteristics studies and its chemical properties, there is a proper opportunity for the success of small to create a success small distillation projects for domestic uses in faraway areas.

4. Iraq and Syria have built their own big dams on the Tigris and Euphrates Rivers, this led to shortage in surface water, in stead groundwater might be substitute, so discharging groundwater in a high quantity may also led to decreasing in its quantity, besides changing in its quality. Therefore, monitoring its quality will be obligate.

5. The problem of deteriorating water quality across the region is eclipsed by concerns over quantity. However, increasing levels of pollution and salinity of 
both surface and groundwater resources is increasingly affecting the ability to use the scarce water resources available in the region, and is heightening tensions between riparian countries. In addition, while environmental agencies consider the need for minimal environmental flows to maintain ecosystems, this issue is rarely incorporated in national water management planning in the region.

6. The salinity of the Euphrates water is considered not acceptable for drinking purposes before it enters the Iraqi border while the Tigris water becomes unacceptable downstream Baghdad.

7. Water quality deterioration in both rivers is due to several factors, construction of dams increased evaporation from the reservoirs. In addition, as more water is used for irrigation purposes the returned irrigation water is expected to seep back to the irrigation network at the absence of drainage systems. Moreover, even at the presence of such systems, drainage water is sometimes discharged directly to the rivers causing increase in salinity. The process is becoming more intensive with the increase of temperatures and decrease of precipitation due to climate change.

8. Other sources for water quality deterioration and pollution includes: discharge of wastewater to the rivers, discharging solid waste to the rivers, the use of AlTharthar reservoir water to back up Euphrates and Tigris rivers basins shortages, pollution due to remnants of wars and increase in water consumption due to high population growth rates.

9. Establish water quality monitoring and assessment collaboration across Iraqi region.

10. Strict establishment for the regular quantitative monitoring surface water and groundwater setting and processes.

11. Future prospects are more negative for all riparian countries. This implies that solving these problems requires actual and serious international, regional, and national cooperation to set a prudent plan for water resources management of the two basins. Iraq being the most affected country should seriously set a prudent, scientific, and strategic plan for the management and conservation of its water resources.

12. Development of the Water Quality Index for different purposes in Iraq to classify water quality in terms of suitability for domestic, irrigation and agricultural uses. 


\section{References}

[1] Abahussain, A.A., Abdu, A.S., Al-Zubari, W.K., El-Deen, N.A. and AbdulRaheem, M. (2002). Desertification in the Arab region: analysis of current status and trends. J Arid Environ 51:pp.521-545.

[2] Abdullah, A. D. (2016). Modelling Approaches to understand Salinity Variation in Highly Dynamic Tidal River, The case of the Shatt Al-Arab River. $\mathrm{PhD}$ thesis, Delft University of Technology and of the Academic Board of the UNESCO-IHE, Delft, the Netherlands.

[3] Abdullah, A. D. (2016). Modelling Approaches to understand Salinity Variation in Highly Dynamic Tidal River: The case of the Shatt Al-Arab River. $\mathrm{PhD}$ thesis, Delft University of Technology and of the Academic Board of the UNESCO-IHE, Delft, the Netherlands.

[4] Adamo, N., Al-Ansari, N., Sissakian, V.K., Knutsson, S. and Laue, J. (2018). Climate change: consequences on Iraq's environment. Journal of Earth Sciences and Geotechnical Engineering, Vol.8, No.3, pp.43-58.

[5] Akada, A., Freeman, S. and Placht, M. (2007). The Tigris-Euphrates river Basin: Mediating a Path towards Regional Water Stability. Al Nakhlah, Spring,63-74.

[6] Akanda, A., Freeman, S. and Placht, M. (2007). The Tigres-Euphrates River Basin: Mediating a Path Towards Regional Water Stability

[7] Al Bomola, A. (2011). Temporal and spatial changes in water quality of the Euphrates river-Iraq. MSc thesis, University of Lund, Lund Sweden. Available at: http://lup.lub.lu.se/luur/download?func=downloadFile\&recordOId=2341931 \&fileOId=2341934 Last accessed February 2018.

[8] Alalaf, I. (2009). Ilisu dam and its effect on man and environment in Iraq and Turkey, Batnaya.

[9] Al-Ansari, N. (2013). Management of water resources in Iraq: perspectives and prognoses. Engineering Vol., pp.667-684.

[10] Al-Ansari, N., AlJawad, S., Adamo, N., Sissakian, V.K., Laue, J. and Knutsson, S. (2018). Water quality within the Tigris and Euphrates catchments. Journal of Earth Sciences and Geotechnical Engineering, Vol.8, No.3, pp.95-121.

[11] Al-Ansari, N. (2016). Hydropolitics of the Tigris and Euphrates Basins. Engineering, Vol.8, Issue 3, pp.140-172.

[12] Al-Fatlawi, A.N. (2010). Geological and Hydrogeological Characteristics of Umm Er Radhuma aquifer West of Iraq. Euphrates Journal of Agriculture Science, Vol. 2, No. 4 p. 263-275

[13] Al-Hadithi, A.H. (1978). Optimal utilization of the water resources of the Euphrates River in Iraq. Doctoral Dissertation, University of Arizona.

[14] Al-Jiburi, H.K. and Al-Basrawi, N.H. (2015). Hydrogeological map of Iraq, scale 1: 1,000,000, 2nd edition, Iraqi Bulletin of Geology and Mining, Vol.11, No.1, p. 17-26. 
[15] Alsaka, L.Y. (2014). Concepts of Water Management among Riperian Countries (Iraq-Turkey-Syria) and its Implication on Water Quality and Quantity. J. University of Duhok,17,1, pp.81-94.

[16] Al-Shaab, T. (2017). Interview with the Iraqi Minister of Water Resources, 22nd June, 2017. Issue number 212, year 82 . Available at: http://tareeqashaab.com/images/TariqPDF/2017/6/22.pdf last accessed 30 January, 2018.

[17] Amin, M.T., Mahmoud, S.H. and Alazba, A.A. (2016). Observations, projections and impacts of climate change on water resources in Arabian peninsula: current and future scenarios. Environ Earth Sci 7, pp.:1-17. https://doi.org/10.1007/s12665-016-5684-4

[18] Bayazit, M. and Avci, I. (1997). Water resources of Turkey: potential, planning, development and management. Water Resour Dev 13:443-452.

[19] Bilgen, A. (2018). The southeastern Anatolia project (GAP) revisited: the evolution of GAP over forty years. New Perspect Turk 58:125-154. https://doi.org/10.1017/npt.2018.8.

[20] Buringh, P. (1960). Soils and soil condition in Iraq. Ministry of Agriculture, Baghdad, Iraq.

[21] Chabuk, A., Al-Madhlom, Q., Al-Maliki, A., Al-Ansari, N., Hussain, M. and Laue, J. (2020). Water quality assessment along Tigris River (Iraq) using water quality index (WQI) and GIS software. Arabian Journal of Geosciences (2020) 13:654 https://doi.org/10.1007/s12517-020-05575-5.

[22] Chulov, M. (2010). Iraq littered with high levels of nuclear and dioxin contamination, study finds, guardian.co.uk, 22 January 2010.

[23] Economic and Social Commission for Western Asia (ESCWA), (2003). An Evaluation of the Economic, Social and Drought-Related Impact, Report number E/ESCWA/SDPD/2003/13. http://www.un.org/waterforlifedecade/pdf/2003_unescwa_sectoral_water_all ocation_policies_eng.pdf

[24] Economic and Social Commission for Western Asia (ESCWA) (2013). Inventory of Shared Water Resources in Western Asia, Salim Dabbous Printing Co., Beirut, Lebanon, p.626.

[25] Ewaid, S. H., Abed, S. A., Al-Ansari, N., and Salih, R. M. (2020). Development and Evaluation of a Water Quality Index for the Iraqi Rivers. Hydrology, 7(3), 67.

[26] FAO (Food and Agricultural Organization), (2009)a. Turkey, Water Report 34. http://www.fao.org/nr/water/aquastat/countries_regions/TUR/ Last accessed February 2018.

[27] FAO (Food and Agricultural Organization), (2009)b. Syria, Water Report 34. http://www.fao.org/nr/water/aquastat/countries_regions/SYR/ Last accessed February 2018.

[28] FAO (Food and Agricultural Organization), (2009)c. Iraq, Water Report 34. http://www.fao.org/nr/water/aquastat/countries_regions/IRQ. Last, accessed February 2018. 
[29] Food and Agriculture Organization (FAO) (2017). Water resources. Available at : http://www.fao.org/nr/water/aquastat/water_res/index.stm

[30] Frenken, K. (2009). Irrigation in the Middle East region in figures, AQUASTAT Survey-2008. FAO water reports. Published by food and agriculture Organization of the United Nations (FAO), Rome, Italy, 34. ISSN 1020-120.

[31] Gassert, F., Reig, P., Luo, T. and Maddocks, A. (2013). Aqueduct country and river basin rankings: a weighted aggregation of spatially distinct hydrological indicators. Working paper, Washington, DC: World Resources Institute. November. http://wri.org/publication/aqueductcountry-river-basin-rankings

[32] Geopolicity (2010). Managing the Tigris-Euphrates watershed: The challenge facing Iraq, part III structural drivers of change, p 24.

[33] Horton, R.K. (1965). An Index Number System for Rating Water Quality. Journal of the Water Pollution Control Federation, 37, 300-306. http://www.scirp.org/(S(i43dyn45teexjx455qlt3d2q))/reference/Ref erencesPapers.aspx?ReferenceID $=1020268$

[34] Hillel, D. (1994). Rivers of Eden: The Struggle for Water and the Quest for Peace in the Middle East. Oxford University Press, New York.

[35] International Organization for Migration (IOM) (2020). Water quantity and water quality in central and south Iraq. Report by the United Nations Migration Agency, a preliminary assessment in the context of displacement risk.

[36] IPCC Intergovernmental Panel on Climate Change (2007)a. Climate change 2007: climate change impacts, adaptation and vulnerability. Cambridge University Press, Geneva.

[37] Jammali, H. and Sullivan, C. (2012). Multidimensional analysis of water poverty in the MENA region. Social Indicators Research, 115, 1, pp.253-77, http://link.springer.com/journal/11205 .

[38] Jones, C., Sultan, M., Yan, E., Milewski, A., Hussein, M., Al-Dousari, A., AlKaisy, S., and Becker, R. (2008). Hydrologic Impacts of Engineering Projects on the Tigris-Euphrates System and its Marshes. Journal of Hydrology, 353, pp.59-75.

[39] Kliot, N. (1994). The Geopolitics of Inequality: The Tigris-Euphrates Drainage Basin. In Water Resources and Conflict in the Middle East. Published by Routledge. London/New York.

[40] Krasny, J., Alsam, S. and Jassim, S.Z., Hydrology, in Jassim, S.Z. and Goff, J.C. (eds.). (2006). Geology of Iraq, Czechrepublic, Brno, pp.251-287.

[41] Maddocks, A., Young, R.S. and Reig, P. (2015). Ranking the World's Most Water-Stressed Countries in 2040. World Resources Institute. Available at: http://www.wri.org/blog/2015/08/ranking-world\%E2\%80\%99s-most-waterstressed-countries-2040 Last accessed February 2018.

[42] Majeed, Y. A. (1993). The central Regions: Problems and Perspectives, in Roger, R. and Lydon, P. (Eds.). Water in the Arab Word: Perspectives and Prognoses, Harvard University, pp.101-120. 
[43] MICS (Multiple Indicator Cluster Survey) (2011). IRAQ: Monitoring the situation of children and Women, Final Report, https://mics-surveysprod.s3.amazonaws.com/MICS4/Middle\%20East\%20and\%20North\%20Afri ca/Iraq/2011/Final/Iraq\%202011\%20MICS_English.pdf Last accessed February 20, 2018.

[44] Ministry of Industry and Technology (2019). What's Gap. Southeastern Anatolia Project, Regional Development Administration, Turkey, home. http://www.gap.gov.tr/en/what-s-gap-page-1.html. Accessed 28 October.

[45] Ministry of Planning/Central Organization for Statistics and Information Technology (COSIT), Ministry of Municipalities and Public Works, Ministry of Environment, Baghdad Municipality, Ministry of Planning/Statistics Office of the Kurdistan Region, Ministry of Municipalities of the Kurdistan Region, Ministry of Environment of the Kurdistan Region, in cooperation with UNICEF (2011). Environmental Survey in Iraq (2010).

Water-Sanitation-Municipal Services. Available at: reliefweb.int/sites/reliefweb.int/files/resources/Full_Report_2732.pdf, accessed 6 June (2016).

[46] Ministry of Planning/Central Organization for Statistics and Information Technology (COSIT), Ministry of Municipalities and Public Works, Ministry of Environment, Baghdad Municipality, Ministry of Planning/Statistics Office of the Kurdistan Region, Ministry of Municipalities of the Kurdistan Region, Ministry of Environment of the Kurdistan Region, in cooperation with UNICEF (2011). Environmental Survey in Iraq 2010: Water-SanitationMunicipal Services. Available at: reliefweb.int/sites/reliefweb.int/files/resources/Full_Report_2732.pdf, accessed 6 June (2016).

[47] Ministry of Water Resources of Iraq (2014). Strategy for Water and Land Resources of Iraq 2015-2035.

[48] Ministry of Water Resources of Iraq. (2014). Strategy for Water and Land Resources of Iraq 2015-2035.

[49] Ministry of Environment of Iraq (MEI), (2013). National Environmental Strategy and Action Plan for Iraq 2013-2017.

[50] Population Reference Bureau (2015). World Population Data with a special focus on women's. Available at: http://www.prb.org/pdf15/2015-worldpopulation-data-sheet_eng.pdf Last accessed February 2018.

[51] Proyect, L. (2018). Iran`s Water Crisis, Counter punch, January 10, 2018. Available at: https://www.counterpunch.org/2018/01/10/irans-water-crisis/ last accessed 30 January.

[52] Saleh, S.A., Al-Ansari, N. and Abdullah, T. (2020). Groundwater Hydrology in Iraq. Journal of Earth Sciences and Geotechnical Engineering, Vol.10, No. 1, 2020, pp.155-197, ISSN: 1792-9040 (print version), 1792-9660 (online). 
[53] Schnepf, R. (2003). Iraq's Agriculture: Background and Status, Congressional Research Service, The Library of Congress. Available at: http://nationalaglawcenter.org/wp-content/uploads/assets/crs/RS21516.pdf last accessed February 2018.

[54] Shamout, N. and Lahn, G. (2015). The Euphrates in Crisis: Channels of Cooperation for a Threatened River. Chatham House, The Royal Institute of International Affairs, Research paper pp.45. https://www.chathamhouse.org/sites/files/chathamhouse/field/field_documen t/20150413Euphrates_0.pdf

[55] Sharifikia, M. (2013). Environmental challenges and drought hazard assessment of Hamoun Desert Lake in Sistan region, Iran, based on the time series of satellite imagery. J. Natural Hazards, 65, pp.201-217, DOI 10.1007/s11069-012-0353-8.

[56] Sissakian, V., Al-Ansari, N.A. and Knutsson, V. (2013). Sand and dust storm events in Iraq. J. Natural Science, V 5, 10, pp.1084-1094.

[57] Sissakian, V.K. (2011). Origin of the Tharthar Depression, Central part of Iraq. Iraqi Bulletin of Geology and Mining, Vol. 7, No.3, p. 47 - 62.

[58] Sluglett, P. (2003). The international context of Iraq from 1980 to the present. In E. Nicholson, \& P. Clark (eds)., The Ira New Eden master plan for the integrated water resources management in the Marshland area, Politico's Publishing.

[59] Solomon, S. (2010). Water: the epic struggle for wealth, power, and civilization. Published by Harper Perennial, New York, USA ISBN 978-0-06054831-5.

[60] Tkachenko, A. (2003). The economy of the Iraqi Marshes in the 1990s. In E.

[61] UN Water, 2016 (2016). Water and Jobs facts and figures: The United Nations World Water Development Report,12p. Available at: http://unesdoc.unesco.org/images/0024/002440/244041e.pdf Last accessed February, 2018.

[62] UNDP (United Nations Development Program) (2011). Drought Impact Assessment, Recovery and Mitigation Framework and Regional Project Design in Kurdistan Region (KR), p.79. Available at:

http://www.undp.org/content/dam/rbas/report/Drought.pdf last accessed February, 2018.

[63] UNEP (United Nations Environmental Program) (2003). Desk Study on the environment of Iraq. Switzerland, p.96.

[64] UN-ESCWA and BGR (United Nations Economic and Social Commission for Western Asia; Bundesanstalt für Geowissenschaften und Rohstoffe). (1999).

[65] UNICEF, (2003). Iraq watching briefs, Water and Environmental Sanitation, p.64. 8 https://www.unicef.org/evaldatabase/index_29697.html Last accessed February 20, 2018.

[66] United Nations Educational, Scientific, and Cultural Organization (UNESCO) (2014). Integrated Drought Risk Management National Framework for Iraq: An Analysis Report. 
[67] Voss. K.A., Famiglietti, J.S., Lo, M., De Linage, C., Rodell, M. and Swenson, S.C. (2013). Groundwater depletion in the Middle East from GRACE with implications for Transboundary water Management in the Tigris-EuphratesWestern Iran Region. Water Resour Res 49:904-914.

[68] Wikipedia (2018). Mesopotamia. Available at:https://simple.wikipedia.org /wiki/ Mesopotamia Last accessed March, 2018.

[69] Wikipedia, the free encyclopedia (2011). Information about Iraq, available at http://en.wikipedia.org/wiki/Iraq\#Geography, retrieved 21 Jon 2011.

[70] World Health Organization (WHO) (2012). Cholera in Iraq.

[71] Worldmeters (2008). Countries in the world by population. Available at: http://www.worldometers.info/world-population/population-by-country/ Last accessed February, 2018.

[72] Zwijnenburg, W. (2013). In the state of Uncertainty: Impact and implications of the use of deleted uranium in Iraq, IKV PAX C. 